\title{
Hair Cell Replacement in Adult Mouse Utricles after Targeted Ablation of Hair Cells with Diphtheria Toxin
}

\author{
Justin S. Golub, ${ }^{1}$ Ling Tong, ${ }^{1}$ Tot B. Ngyuen, ${ }^{1}$ Cliff R. Hume, ${ }^{1}$ Richard D. Palmiter, ${ }^{2}$ Edwin W. Rubel, ${ }^{1}$ \\ and Jennifer S. Stone ${ }^{1}$ \\ ${ }^{1}$ The Virginia Merrill Bloedel Hearing Research Center and the Department of Otolaryngology-Head and Neck Surgery and ${ }^{2}$ The Howard Hughes Medical \\ Institute and the Department of Biochemistry, University of Washington, Seattle, Washington 98195
}

We developed a transgenic mouse to permit conditional and selective ablation of hair cells in the adult mouse utricle by inserting the human diphtheria toxin receptor (DTR) gene into the Pou4f3 gene, which encodes a hair cell-specific transcription factor. In adult wild-type mice, administration of diphtheria toxin (DT) caused no significant hair cell loss. In adult Pou4f3 ${ }^{+/ D T R}$ mice, DT treatment reduced hair cell numbers to $6 \%$ of normal by 14 days post-DT. Remaining hair cells were located primarily in the lateral extrastriola. 0 ver time, hair cell numbers increased in these regions, reaching $17 \%$ of untreated Pou $4 f^{+/ D T R}$ mice by 60 days post-DT. Replacement hair cells were morphologically distinct, with multiple cytoplasmic processes, and displayed evidence for active mechanotransduction channels and synapses characteristic of type II hair cells. Three lines of evidence suggest replacement hair cells were derived via direct (nonmitotic) transdifferentiation of supporting cells: new hair cells did not incorporate BrdU, supporting cells upregulated the pro-hair cell gene Atoh1, and supporting cell numbers decreased over time. This study introduces a new method for efficient conditional hair cell ablation in adult mouse utricles and demonstrates that hair cells are spontaneously regenerated in vivo in regions where there may be ongoing hair cell turnover.

\section{Introduction}

Hair cells are sensory mechanotransducers in the inner ear that are required for hearing, balance, and body orientation. The innate capacity for hair cell replacement after injury has been probed in mammals since it was reported in birds (Corwin and Cotanche, 1988; Jørgensen and Mathiesen, 1988; Ryals and Rubel, 1988). While spontaneous hair cell replacement does not occur in the cochlea's organ of Corti (Forge et al., 1998), it occurs to some degree in mature mammalian vestibular end organs, such as the utricle (Forge et al., 1993, 1998; Warchol et al., 1993; Rubel et al., 1995; Walsh et al., 2000; Oesterle et al., 2003; Kawamoto et al., 2009; Wang et al., 2010; Lin et al., 2011). However, several features of hair cell regeneration in vestibular or-

Received April 7, 2012; revised July 9, 2012; accepted Aug. 27, 2012.

Author contributions: J.S.G., L.T., R.D.P., E.W.R., and J.S.S. designed research; J.S.G., L.T., T.B.N., R.D.P., E.W.R., and J.S.S. performed research; C.R.H. and R.D.P. contributed unpublished reagents/analytic tools; J.S.G., T.B.N., R.D.P., E.W.R., and J.S.S. analyzed data; J.S.G. and J.S.S. wrote the paper.

This work was supported by NIH Grants R01 DC003696 (J.S.S.), T32 DC00018 (J.S.G.), R01 DC003829 (E.W.R.), K08 DC006437 (C.R.H.), P30 DC04661 (J.S.S., E.W.R., C.R.H.), the Oberkotter Foundation (J.S.S., E.W.R., C.R.H.), and the Howard Hughes Medical Institute (R.D.P.). From the University of Washington, we thank Elizabeth Oesterle for helpful discussions, Linda Robinson and Bruce Tempel for assistance with mouse husbandry and genotyping, James Phillips for assistance with analyzing mouse behavioral phenotypes, Glen MacDonald for assistance with digital imaging, Kevin Whitham and Brandon Warren for help with data management, and Dale Cunningham for assistance with plastic sections. We also thank Jane Johnson from Southwestern Texas Medical University for the Atoh1 reporter construct.

E.W.R. and J.S.S. share senior authorship of this manuscript.

The authors declare no competing financial interests.

Correspondence should be addressed to Dr. Jennifer S. Stone, CHDD CD176 Box 357923, Virginia Merrill Bloedel Hearing Research Center, Department of Otolaryngology-Head and Neck Surgery, University of Washington, Seattle, WA 98195-7923. E-mail: stoner@u.washington.edu.

DOI:10.1523/JNEUROSCI.1709-12.2012

Copyright $\odot 2012$ the authors $\quad 0270-6474 / 12 / 3215093-13 \$ 15.00 / 0$ gans-including the types of hair cells that are formed and the mechanisms that guide this process - remain unclear.

Due to the ease of genetic manipulation, mice are the preferred mammalian model for studies of hair cell regeneration. The most frequently used agents for experimental hair cell destruction - aminoglycoside antibiotics - are problematic in mature mice. To achieve sufficient lesions with minimal mortality, aminoglycosides must be repeatedly injected at low doses (Forge and Schacht, 2000; Wu et al., 2001; Staecker et al., 2007). Lesions to both the cochlear and vestibular epithelia are highly variable and usually incomplete, which makes it difficult to distinguish regions of regeneration. Injection of a second ototoxic agent increases cochlear but not vestibular hair cell loss (Oesterle et al., 2008; Taylor et al., 2008). Local administration (Nakagawa et al., 2003; Heydt et al., 2004; Staecker et al., 2007; Kawamoto et al., 2009; Wanamaker et al., 1998) avoids systemic toxicity, but surgeries are technically challenging and results are highly variable. Aminoglycoside-induced hair cell loss is incomplete in vitro, and tissues thrive for only 1 month (Cunningham et al., 2002; Lin et al., 2011). Aminoglycosides could also injure other cells besides hair cells, hampering data interpretation and confounding measurements of recovery (Aran et al., 1995).

We sought an improved approach for studying hair cell damage and replacement in adult mammals by generating transgenic mice with the capacity for targeted, inducible hair cell ablation in vivo or in vitro. The gene encoding the human diphtheria toxin receptor $(h u D T R)$ was placed downstream of the Pou $4 \mathrm{f} 3$ promoter, whose activity in the inner ear is limited to differentiated hair cells (Erkman et al., 1996; Xiang et al., 1997). Mice are 10,000 times more resistant to diphtheria toxin (DT) than humans (Me- 
kada et al., 1982; Pappenheimer et al., 1982). Therefore, systemic administration of small amounts of DT to mice should cause selective ablation of hair cells without side effects (Palmiter, 2001; Saito et al., 2001). Here, we show that two intramuscular injections of DT caused nearly complete loss of hair cells in the utricle and that over time some hair cells were replaced, apparently by transdifferentiation of supporting cells.

\section{Materials and Methods}

Mice. Three strains of mice were used in this study: mixed C57BL6/J $\times$ 129Sv, C57BL6/J, and CBA/J. All data presented are derived from mixed C57BL6/J $\times 129$ Sv or C57BL/6 mice, unless indicated. Similar results were obtained in experiments with each strain. Males and females were used between 6 and 26 weeks (180 days) of age. Mice were housed with open access to food and water. For preparation of fixed tissues, mice were killed by $\mathrm{CO}_{2}$ inhalation followed by decapitation. For culture experiments, mice were killed by cervical dislocation followed by decapitation. All procedures were approved by the Institutional Animal Care and Use Committee at the University of Washington (Seattle, WA) and adhere to standards of the American Veterinary Medical Association and the National Institutes of Health.

Generation of Pou4f3 ${ }^{\mathrm{DTR}}$ mice. We targeted the human diphtheria toxin receptor (huDTR; heparin-binding epidermal growth factor receptor) to the Pou $4 \mathrm{f} 3$ locus in mice to achieve temporally controlled ablation of hair cells. The strategy that we employed was initially developed to ablate hepatocytes (Saito et al., 2001) and was later used to kill select neurons in the hypothalamus (Luquet et al., 2005) and other cell types in mice. We generated the Pou $4 \mathrm{f}^{\mathrm{DTR}}$ construct as follows. A BsiW1 site was engineered into the first Pou $f 3$ exon just upstream of the initiation codon. A $5.9 \mathrm{~kb}$ SpeI-SnaB1 fragment was cloned into a targeting vector as the $5^{\prime}$ arm upstream of a floxed $S v N e o$ gene, and a $4.4 \mathrm{~kb}$ SnaB1-XbaI fragment was cloned downstream of the floxed $S v N e o$ gene as the $3^{\prime} \mathrm{arm}$. The targeting construct also had flanking Pgk-DTA and HSV-TK genes for negative selection. The full coding region for the $h u D T R$ was cloned into the BsiWI site such that it represented the first open reading frame. A floxed SVNeo gene was removed by breeding with Mox2-Cre mice, and then the Mox2-Cre gene was removed from the background by selective breeding. For routine identification of the targeted allele by polymerase chain reaction, we used these primers: Pou4f3 (wild-type) Forward 5'CAC TTG GAG CGC GGA GAG CTA G; Pou $43^{\text {DTR }}$ (mutant) Reverse 5'CCG ACG GCA GCA GCT TCA TGG TC. All experimental mice were heterozygotes (Pou $\left.43^{+/ D T R}\right)$. Pou $4 \mathrm{f}^{+/ D T R}$ mice were on one of three backgrounds: mixed C57BL/6 $\times 129 \mathrm{~Sv}$, C57BL6/J, or CBA/J. Controls consisted of age-matched and strain-matched wild-type $\left({\left.\text { Pou } 4 \mathrm{f3}^{+/+}\right)}^{+}\right.$ littermates.

Administration of diphtheria toxin in vivo. Diphtheria toxin was purchased from one of two sources: Sigma-Aldrich or List Biological Laboratories. Similar results were achieved with DT from each source. Adult mice (6-9 weeks of age) received two intramuscular injections of DT at $50 \mathrm{ng} / \mathrm{g}$, spaced 2 days apart. Each injection contained $1 \mu \mathrm{g}$ of DT dissolved in $50 \mu \mathrm{l}$ of saline. Mice received $0.4 \mathrm{ml}$ of lactated Ringer's solution by subcutaneous injection once or twice daily on days 3-6 after the first DT injection. Between days 1 and 6 after the first DT injection, food was supplemented with high-calorie gel (Tomlyn/Vétoquinol from Nutri-Cal).

Diphtheria toxin treatment in vitro. Temporal bones were isolated and placed in cold HBSS (Sigma-Aldrich). The bone overlying the utricle was dissected away, and the otoconia and the otoconial membranes were removed using a gentle stream of HBSS from a 26 gauge needle. Utricles were isolated using Dumont microforceps and cultured free-floating in a 96-well plate containing $100 \mu$ l of DMEM (Sigma-Aldrich) and $1 \%$ fetal bovine serum (FBS) (Atlanta Biologicals) at $37^{\circ} \mathrm{C}$ with $95 \%$ air $/ 5 \% \mathrm{CO}_{2}$. Each well contained two utricles. DT was added to culture media for $24 \mathrm{~h}$ at concentrations of $3.3 \mathrm{ng} / \mathrm{ml}, 333 \mathrm{ng} / \mathrm{ml}$, and $3.3 \mu \mathrm{g} / \mathrm{ml}$. Culture plates were rotated for the first $30 \mathrm{~min}$ to distribute fluids and were subsequently kept still. Utricles were washed five times with $100 \mu \mathrm{l}$ of HBSS and then incubated in $100 \mu \mathrm{l}$ of DMEM with $1 \%$ FBS for various periods of time. On each subsequent day, half-volumes of culture media were exchanged.
Table 1. Numbers of utricles used for quantitative analyses

\begin{tabular}{|c|c|c|c|c|c|c|}
\hline Animal type (age) & DT? & $\begin{array}{l}\text { Time of death } \\
\text { post-DT }\end{array}$ & $\begin{array}{l}\text { HC counts } \\
(20 \mathrm{x})\end{array}$ & $\begin{array}{l}\text { SC counts } \\
(60 \mathrm{x})\end{array}$ & $\begin{array}{l}\text { HC counts } \\
(60 x)\end{array}$ & $\begin{array}{l}\text { Bundle } \\
\text { counts }\end{array}$ \\
\hline Wild type (6 -9 weeks) & No & N/A & 4 & 6 & 6 & - \\
\hline Wild type (8-11 weeks) & Yes & 14 days & 4 & 4 & 4 & - \\
\hline \multirow[t]{9}{*}{ Pou4f3 ${ }^{+/ D T R}(6-35$ weeks $)$} & No & $\mathrm{N} / \mathrm{A}$ & 4 & 4 & 4 & 一 \\
\hline & Yes & 7 days & 7 & - & - & 4 \\
\hline & Yes & 14 days & 5 & 3 & 3 & 4 \\
\hline & Yes & 21 days & 8 & - & - & - \\
\hline & Yes & 28 days & 6 & - & 一 & - \\
\hline & Yes & 40 days & 4 & 4 & 4 & 4 \\
\hline & Yes & 60 days & 10 & 10 & 10 & 4 \\
\hline & Yes & 90 days & 7 & 6 & 6 & 4 \\
\hline & Yes & 180 days & 2 & 2 & 2 & 2 \\
\hline
\end{tabular}

FM1-43 labeling. For these experiments, all steps were performed using warm $\left(37^{\circ} \mathrm{C}\right)$ solutions, and all incubations occurred at $37^{\circ} \mathrm{C}$ with $95 \%$ air $/ 5 \% \mathrm{CO}_{2}$. Utricles from adult wild-type mice and utricles from adult Pou $4 \mathrm{f}^{+/ D T R}$ mice at 80 days post-DT were explanted, and otoconia were removed as described above. Utricles were incubated in HBSS for 5 min and then in HBSS containing $5 \mu \mathrm{M}$ FM1-43 (Invitrogen) for 1 min. Utricles were then rinsed two times with HBSS, incubated in HBSS for 30 more minutes, and fixed with $4 \%$ paraformaldehyde for $30 \mathrm{~min}$. Utricles were then labeled for phalloidin to assess bundle morphology.

BrdU administration. Drinking water was supplemented with $2 \mathrm{mg} / \mathrm{ml}$ BrdU (5-bromo-2'-deoxyuridine; Sigma-Aldrich) for 1 week during the following five periods post-DT: days $0-7,8-14,5-21,22-28$, or 53-60. BrdU solution was made fresh at the beginning of each administration period and was shielded from light with aluminum foil during administration. For comparison, we also examined BrdU labeling in mice that received intraperitoneal BrdU (dissolved in sterile PBS) at $50 \mathrm{mg} / \mathrm{kg}$ once a day between days 0 and 7 post-DT.

Adenovirus transduction in vitro. All methods closely followed those described in Lin et al. (2011). Briefly, adenovirus serotype 5 (Ad5) was engineered to drive GFP expression under control of Atoh1 enhancer elements. The J2XnGFP fragment containing mouse Atoh1 enhancer sequences, GFP, the $\beta$-globin gene promoter, a nuclear localization signal sequence, and the bovine-growth hormone polyadenylation signal (courtesy of Jane Johnson, University of Texas Southwestern Medical School, Dallas, TX) (Helms et al., 2000) was cloned into Ad5 to generate Ad5-Atoh1-GFP. Utricles were explanted from adult wild-type mice and Pou $4 \mathrm{f3}^{+/ D T R}$ mice at 7,14 , and 28 days post-DT. They were placed at a density of 1-2 utricles/well in $50 \mu \mathrm{l}$ of culture media in a 96-well plate. Media contained $4 \times 10^{8}$ optical particle units of virus. Utricles were incubated for $\sim 16 \mathrm{~h}$ in viral solution at $37^{\circ} \mathrm{C}$ on a rotator. Following rinsing, utricles were cultured for 5 days in virus-free media. We examined four utricles for each time point.

Histological methods. Proteins were detected in whole-mount utricles using standard immunofluorescence labeling methods. Utricles were fixed with phosphate-buffered $4 \%$ paraformaldehyde (Sigma-Aldrich) for $30 \mathrm{~min}$, rinsed with PBS, and incubated for $30 \mathrm{~min}$ in blocking solution (2\% bovine serum albumin, $0.8 \%$ normal goat serum, $0.5 \%$ Triton X-100 for myosin VIIa detection or $0.5 \%$ Triton X-100 in PBS with 5\% normal serum for detection of other antigens). Utricles were incubated overnight at $4^{\circ} \mathrm{C}$ with one of the following primary antibodies diluted $1 / 100$ to $1 / 1500$ in blocking solution: rabbit anti-myosin VIIa (Proteus Biosciences), rabbit anti-calbindin D28k (Millipore Bioscience Research Reagents), mouse anti-GFP (Invitrogen), rabbit anti-GFP (Invitrogen), chicken anti-neurofilament (Millipore), rat anti-BrdU (Sigma), mouse anti-acetylated tubulin (Sigma-Aldrich), and mouse anti-Ctbp2 (BD Transduction Laboratories). Secondary antibodies, conjugated to Alexa Fluor 488, 594, or 647 and diluted 1/300, were purchased from Invitrogen. To label filamentous actin, organs were soaked in phalloidin conjugated to Alexa Fluor 488 (Invitrogen) at $10 \mu \mathrm{g} / \mathrm{ml}$, with $0.5 \%$ Triton $\mathrm{X}-100$ in PBS. To label cell nuclei, organs were soaked in 4',6-diamidino2-phenylindole (DAPI) (Sigma-Aldrich) at $1 \mu \mathrm{g} / \mathrm{ml}$ for $10 \mathrm{~min}$. 
A
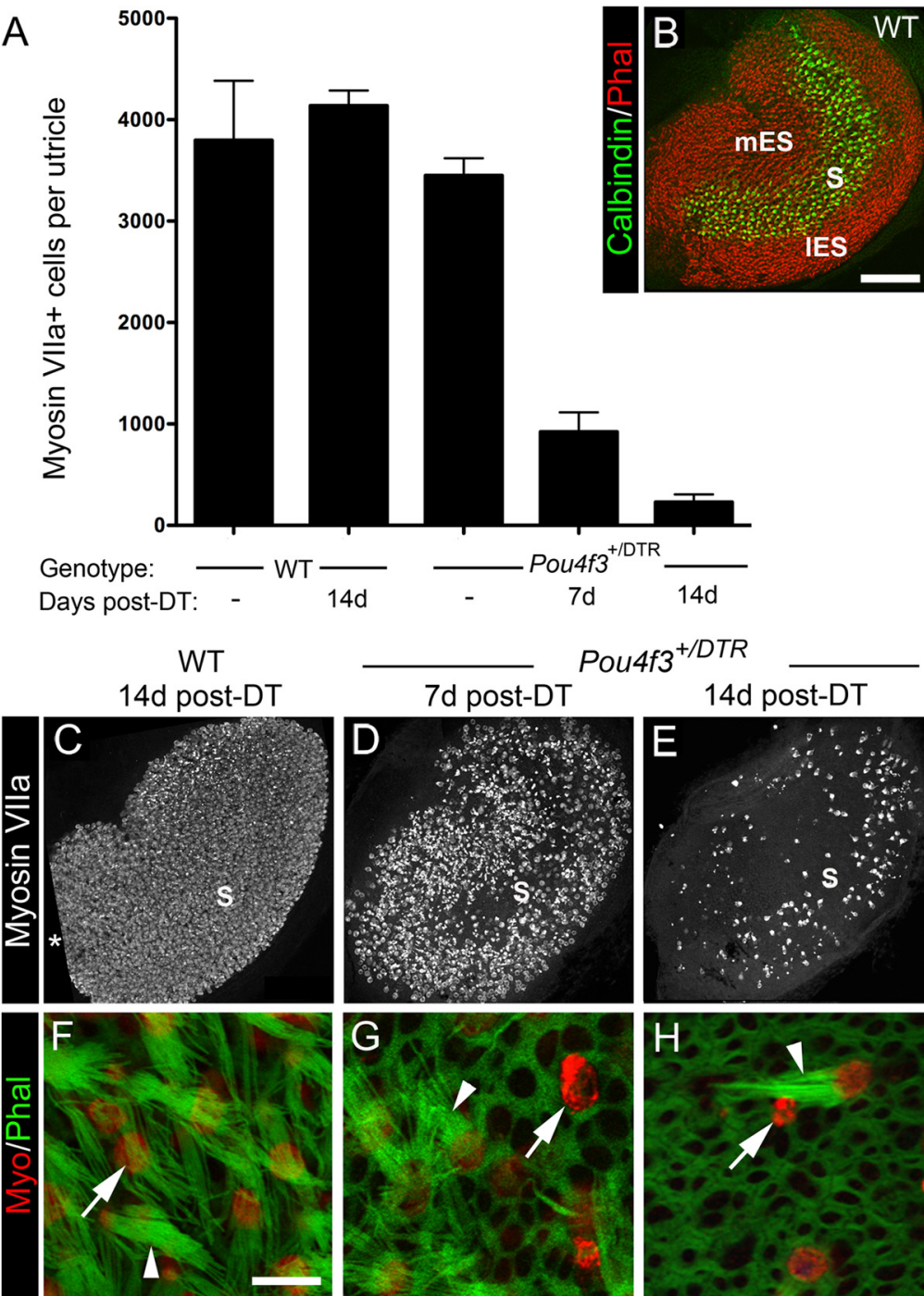

Pou4f3 ${ }^{+/ D T R}$

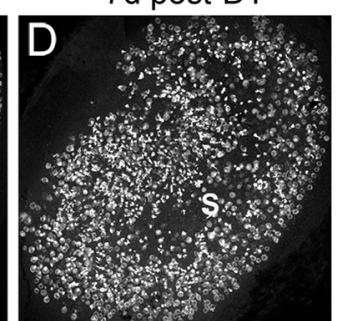

14d post-DT
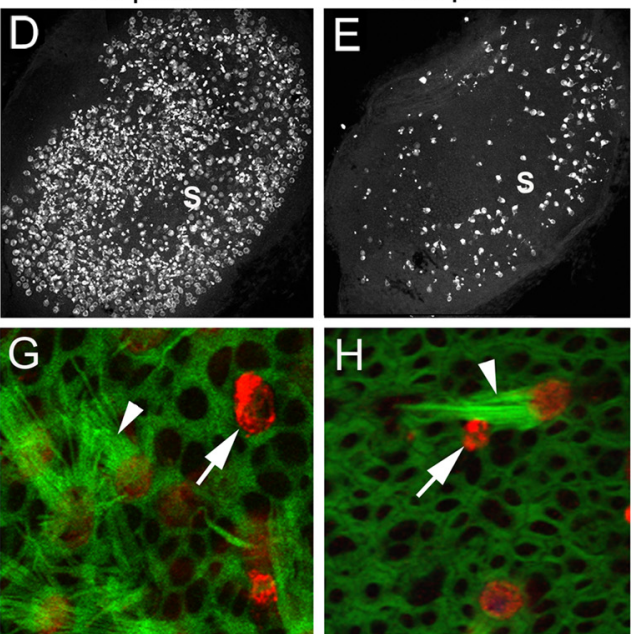

Figure 1. Pou4 $43^{+/ D T R}$ mice show significant loss of hair cells after in vivo DT treatment. Hair cell loss was assessed qualitatively and quantitatively in adult mice that received either two DT injections or no DT treatment. $\boldsymbol{A}$, Graph shows mean numbers of myosin VIla + cells (hair cells) per utricle ( \pm SD) for the following groups with different genotypes and DT treatments: untreated $(-)$ wild-type (WT) mice, treated WT mice at 14 days post-DT, untreated (-) Pou4f3 ${ }^{+ \text {DTR }}$ mice, and Pou4f3 ${ }^{+/ D T R}$ mice at 7 and 14 days (d) post-DT. Sample numbers for counts are provided in Table 1. B, Confocal brightest point projection image of a whole-mount wild-type (WT) utricle labeled for calbindin D28k (green) and phalloidin (red), illustrating the location of the medial extrastriola (mES), striola (S), and lateral extrastriola (IES). $\boldsymbol{C}-\boldsymbol{E}$, Confocal brightest point projections of whole-mount utricles labeled for myosin VIla from WT mice at 14 days post-DT (C) and Pou4f3 ${ }^{+/ D T R}$ mice at 7 days post-DT (D) and 14 days post-DT (E). Sindicates the approximate position of the striola. All utricles are oriented in the same manner. Asterisk in Cindicates region where sensory epithelium was not imaged. $\boldsymbol{F}-\boldsymbol{H}$, High-magnification confocal slices near the lumenal surface of the sensory epithelium showing myosin VIla (red) and phalloidin labeling (green) from WT mice at 14 days post-DT $(\boldsymbol{F})$ and from Pou4f3 ${ }^{+/ D T R}$ mice at 7 days $(\boldsymbol{G})$ and 14 days post-DT $(\boldsymbol{H})$. Arrowheads in $\boldsymbol{F}-\boldsymbol{H}$ point to long bundles. The arrow in $\boldsymbol{F}$ points to the top of a normal-appearing hair cell. Arrows in $\boldsymbol{G}$ and $\boldsymbol{H}$ point to remaining damaged hair cells or hair cell debris. Scale bars: (in $\boldsymbol{B}) \boldsymbol{B}-\boldsymbol{E}, 100 \mu \mathrm{m}$; (in $\boldsymbol{F}) \boldsymbol{F}-\boldsymbol{H}$, $6 \mu \mathrm{m}$.

Some utricles (with anterior and horizontal ampullae attached) were fixed with $2 \%$ paraformaldehyde $/ 3 \%$ glutaraldehyde in $0.1 \mathrm{~m}$ sodium phosphate (pH 7.4), postfixed with $1 \%$ osmium tetroxide (Electron Microscopy Sciences) in $0.1 \mathrm{M}$ sodium phosphate, embedded using an Eponate 12 kit (Ted Pella Inc.), and sectioned at 1-3 $\mu \mathrm{m}$ with a JOEL Sorval Porter Blum MT2-B ultra-microtome. All utricles were oriented in the same manner (using the attached ampullae for guidance) and sectioned from medial to lateral.

Cellular imaging and analysis. Fluorescent imaging was performed using an Olympus FV-1000 confocal microscope. For all utricles, Z-series images from the lumenal surface of the epithelium through the stroma were obtained using a $20 \times$ objective. In addition, a $60 \times$ oil objective was used to take higher-magnification images of individual areas and exemplary cells. For all qualitative analyses, at least six utricles per time point were examined. Several quantitative analyses were performed and are described below. Sample numbers for all quantitative analyses are either provided below in Materials and Methods, in Table 1, or in the figure legends.

Hair cell and supporting cell counts. Cell counting in $20 \times$ images was performed in Image 1.44 (National Institutes of Health, Bethesda, MD) using the Cell Counter plug-in. For hair cell counts, fifteen $1980 \mu \mathrm{m}^{2}$ regions were randomly chosen as follows. A $12 \times 12$ grid was overlaid on the utricle image, and a random number generator was used to create a list of $X-Y$ coordinates. Corresponding regions on the grid that fell completely within the sensory epithelium were analyzed. The process continued until 15 regions were counted. Counts were summed across areas and averaged across utricles. Then, we computed the area of each utricle's sensory epithelium using ImageJ, which indicated that $19-23 \%$ of the sensory epithelial area was sampled per utricle. Next, we multiplied the summed counts for each utricle by a correction factor (percent of area sampled/100, which ranged from 5.26 to 4.35) to obtain estimates of the total number of hair cells per utricle. To be counted as a hair cell, each cell had to be myosin VIIa + and have a healthy-appearing DAPI-labeled nucleus located in the hair cell layer (upper one-third of the sensory epithelium).

We also assessed hair cell and supporting cell counts using $60 \times$ images to make direct comparisons between hair cell and supporting cell densities in each utricle. Higher magnification was used here to enable better detection of individual supporting cell nuclei. For these counts, four regions per utricle (two peripheral and two central, or $\sim 26 \%$ of the sensory epithelial area) were scanned at $60 \times$ in utricles labeled for myosin VIIa and DAPI. In most cases, striolar, lateral extrastriolar, and medial extrastriolar regions were sampled. Hair cell inclusion criteria are described above. A cell was considered a supporting cell if it had myosin VIIa-negative $(-)$ cytoplasm and a healthyappearing nucleus in the supporting cell layer (lower two-thirds of the epithelium). Hair cell and supporting cell densities (cells $/ \mu \mathrm{m}^{2}$ ) were determined. Supporting cell counts per utricle were also estimated by multiplying average supporting cell densities per utricle by an average utricular area. An average utricular sensory epithelium area was calculated using area measurements of 48 utricles from mice between 42 and 180 days of age. Utricular sensory epithelium area does not systematically change with age, but shows considerable variation within an age (Kirkegaard and Nyengaard, 2005).

Hair cell bundle analyses. We also assessed the percentage of hair cells with long, short, or no stereociliary bundles at different times post-DT. In whole-mount utricles labeled for myosin VIIa and phalloidin, we took $60 \times$ confocal images in five presumed striolar regions and four presumed extrastriolar regions. The total area sampled per utricle was $70,000 \mu \mathrm{m}^{2}$ (or $\sim 42 \%$ of the sensory epithelial area, based on our estimate above). In each region, we scored every myosin VIIa + cell as having a relatively "long bundle," "short bundle," or "no bundle (examples of 
each bundle type are shown in Figs. 4 and 5 of Results), and we determined the total number of myosin VIIa + cells per region. Then, we averaged counts of each bundle type and counts of myosin VIIa + cells in each region across the nine regions for each utricle. These numbers were used to calculate the percentage of each bundle type in each utricle, which were then averaged across utricles to obtain an average percentage for each time-point.

$B r d U$ analysis. To assess cell proliferation in the sensory epithelium, we analyzed BrdU immunolabeling in whole-mount utricles from mice that received BrdU in drinking water or via intraperitoneal injection. The following numbers of utricles were examined for drinking water-delivered BrdU: seven utricles at $0-7$ days post-DT, five utricles at 8-14 days postDT, eight utricles at 5-21 days post-DT, 6 utricles at 22-28 days post-DT, and 10 utricles at 53-60 days post-DT. In addition, we examined eight utricles following intraperitoneal delivery of BrdU (one injection per day) on days $0-7$ post-DT. For all analyses of BrdU incorporation, we used the confocal microscope at $40 \times$ magnification to search for BrdU + cells in each utricular sensory epithelium. As a positive control, we counted BrdU+ cells located in the stromal connective tissue below the sensory epithelium within $5 \mu \mathrm{m}$ from the basal lamina.

Statistical analyses. Throughout the text and in graphs, data are expressed as mean \pm SD. Numerical data were statistically analyzed using ANOVA to assess effects of genotype or time post-DT on cell counts (StatView 4.5, Abacus Concepts) and Fisher's protected least significant difference (PLSD) post hoc tests to assess differences between specific experimental groups. One-way analyses were also performed to assess effects of genotype or time post-DT on cell counts. In addition, we performed a Fisher's exact test of independence using StatView to assess the relationship between bundle length and cell shape among hair cells in DT-treated samples. All effects were considered statistically significant if $p \leq 0.05$.

\section{Results}

Diphtheria toxin ablates most hair cells in the utricles of adult transgenic mice

We created transgenic mice in which the gene encoding the human diphtheria toxin receptor (DTR) gene was inserted into exon 1 of the Pou4f3 gene. POU4F3 is a transcription factor required for hair cell survival in mice (Erkman et al., 1996; Xiang et al., 1997). Transcripts for Pou $4 \mathrm{f} 3$ are abundant in developing and mature hair cells but not in other inner ear cells, such as supporting cells or auditory/vestibular ganglion neurons. Human DTR has a much higher affinity for DT than mouse DTR (Mekada et al., 1982; Pappenheimer et al., 1982). Therefore, administration of low-dose DT to Pou $43^{+/ D T R}$ mice should cause targeted and complete ablation of hair cells without damaging other cells in the inner ear or causing systemic toxicity (Palmiter, 2001; Saito et al., 2001).

First, we assessed utricular hair cells using myosin VIIa immunofluorescence in untreated adult mice (6-9 weeks of age) that were wild-type or heterozygous for the Pou $43^{D T R}$ allele. The number of hair cells per utricle did not differ significantly between these two groups (Fig. $1 A ; p=0.22$ ), and no differences were observed with respect to hair cell appearance (data not shown). These observations suggested that hair cell development and maintenance were not affected in Pou $43^{+/ D T R}$ mice.

To determine whether DT has deleterious effects on hair cells in adult wild-type mice, two intramuscular injections of DT $(1 \mu \mathrm{g}$ in $50 \mu$ l saline) were given with an interval of 2 days. At 14 days post-DT (measured after the first DT injection), numbers of myosin VIIa + hair cells per utricle were not significantly different from those of untreated mice (Fig. $1 A)(p=0.21)$. Hair cell density and distribution appeared normal (Fig. 1C), as did stereociliary morphology as assessed by phalloidin labeling for filamentous actin (Fig. $1 F$ ). Thus, this concentration of DT did not appear to affect utricular hair cells in wild-type mice.

In contrast, significant hair cell loss was seen after DT treatment in adult Pou $43^{+/ D T R}$ mice. At 7 and 14 days post-DT, hair cell numbers were reduced to 22 and $6 \%$ of untreated Pou $43^{+/ D T R}$ mice, respectively (Fig. $1 A, C-E$ ). These numbers were significantly different from the control groups and from each other $(p<0.001)$. At 7 days post-DT, hair cell fragments, disorganized stereociliary bundles, and expanded supporting cell surfaces were evident throughout the utricle (Fig. 1D, G). At 14 days, supporting cells (myosin VIIa- cells) occupied most of the sensory epithelium (Fig. $1 H$ ). Hair cells that remained at this 

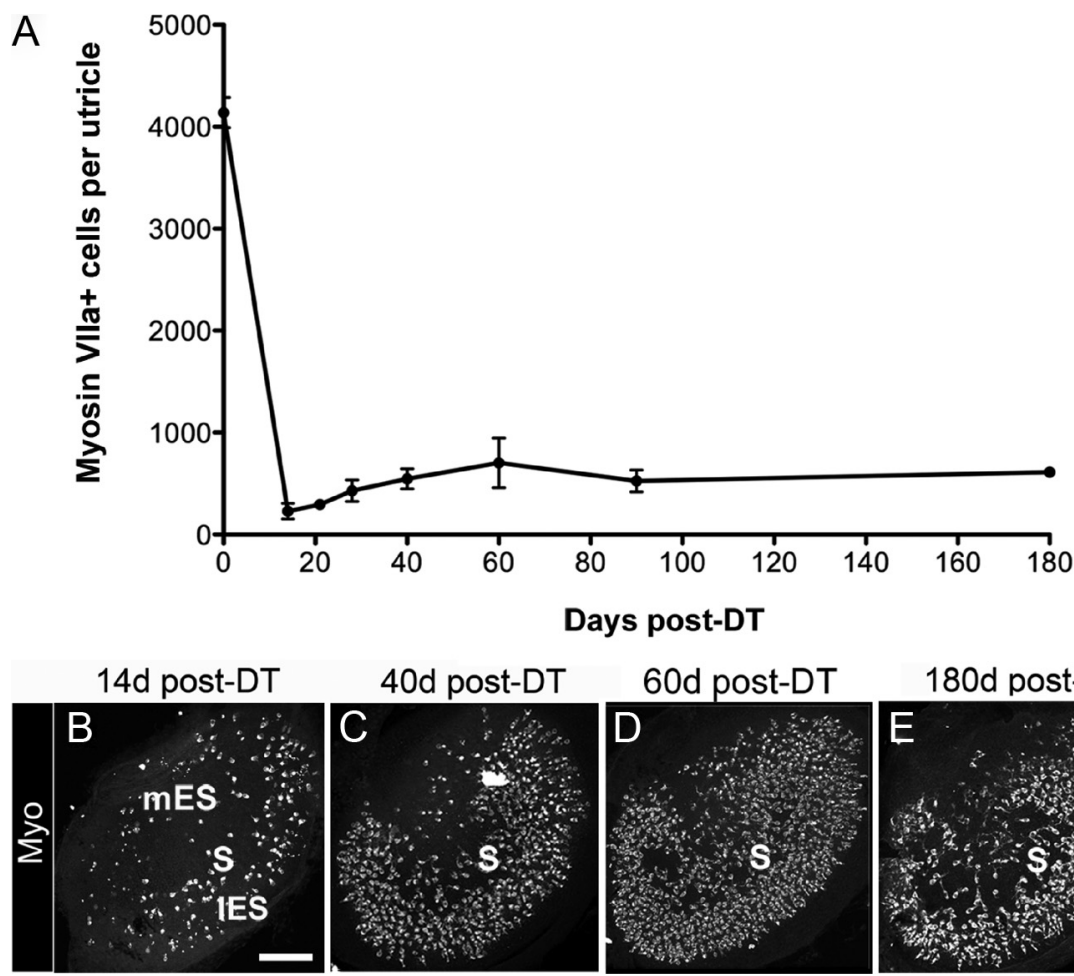

\section{0d post-DT}

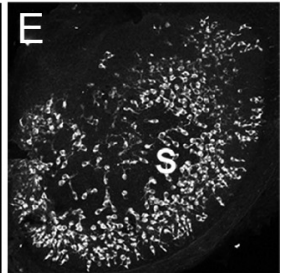

Figure 3. Many hair cells are replaced after in vivo DT treatment. Hair cell replacement was assessed qualitatively and quantitatively in adult Pou $4 f 3^{+/ D T R}$ mice that received two DT injections. $A$, Graph shows mean numbers of myosin VIla + cells ( \pm SD) per utricle in Pou4f3 ${ }^{+/ D T R}$ mice at several times post-DT. Sample numbers for counts are provided in Table 1. $\boldsymbol{B}-\boldsymbol{E}$, Confocal brightest point projection images of myosin VIla (Myo) labeling in utricles at 14 days (d) (B), 40 days (C), 60 days (D), and 180 days $(\boldsymbol{E})$ post-DT.S, mES, and IES indicate the presumed position of the striola, medial extrastriolar region, and lateral extrastriolar region, respectively. Scale bar: (in $\boldsymbol{B}) \boldsymbol{B}-\boldsymbol{E}, 100 \mu \mathrm{m}$.

time had either a long bundle of stereocilia (characteristic of mature hair cells), a very short bundle, or no bundle (Fig. $1 H$ ). They also appeared to be most concentrated in the presumed lateral extrastriolar region of the utricle (Fig. 1E). The lateral extrastriola wraps around the striola, which is a reverse C-shaped area with specialized anatomical features that distinguish it from the medial and lateral extrastriolar regions (Desai et al., 2005; Li et al., 2008). The position of the striola, the lateral extrastriola, and the medial extrastriola in a wild-type untreated utricle are indicated in Figure $1 B$, using immunolabeling for the calciumbinding protein calbindin D28k, which is restricted to hair cells and specialized calyceal nerve endings in the striola. We were unable to trace the position of the striola for long periods after damage, because neural markers for this region did not persist after damage or re-emerge after periods of recovery.

Between 3 and 7 days post-DT, Pou $43^{+/ D T R}$ mice exhibited signs of illness, including vestibulomotor dysfunction (head-bobbing, staggered gait, and circling) and weight loss, which was not seen in injected wild-type littermates. With the assistance of fluid injections and high-calorie food supplementation, these symptoms typically improved by 8 days post-DT. However, a weak vestibulomotor phenotype was retained in most mice as late as 180 days post-DT. Approximately $10 \%$ of mice had to be euthanized due to sustained vestibulomotor problems and weight loss.

To determine whether a higher dose of DT could induce complete hair cell loss, adult Pou $43^{+/ D T R}$ mice were injected with 2 $\mu \mathrm{g}$ of DT in $50 \mu \mathrm{l}$ saline via the same route and schedule and were killed 7 days post-DT. This treatment resulted in no discernible increase in hair cell loss compared to the lower DT dose (data not shown), but it caused greater illness in the mice.
Next, we tested whether DT treatment of adult utricles in vitro could trigger greater hair cell loss than treatment in vivo. Utricles were explanted from wildtype or Pou $43^{+/ D T R}$ mice, cultured overnight with DT at a final concentration of $3.3 \mathrm{ng} / \mathrm{ml}, 333 \mathrm{ng} / \mathrm{ml}$, or $3.3 \mu \mathrm{g} / \mathrm{ml}$, and maintained for 5 additional days in control media. Wild-type utricles treated with $333 \mathrm{ng} / \mathrm{ml}$ DT had 1665 ( \pm 730$)$ myosin VIIa + hair cells (Fig. $2 A, D$ ), which was $44 \%$ of wild-type utricles that were not cultured (confer with Fig. 1). This hair cell loss was likely due to culture conditions rather than DT toxicity, since a similar degree of hair cell loss occurs in utricles from adult Swiss Webster mice when cultured without ototoxin (Lin et al., 2011). Treatment of Pou $4 \mathrm{f3}^{+/ D T R}$ utricles with $3.3 \mathrm{ng} / \mathrm{ml} \mathrm{DT}$ caused loss of nearly all hair cells (Fig. $2 B, D)$. Remaining hair cell numbers were $1 \%$ of numbers in wild-type utricles that were not cultured. There was no significant increase in hair cell loss when the DT dose was increased to either 333 ng/ml (Fig. $2 C, D$ ) or $3 \mu \mathrm{g} / \mathrm{ml}$ (data not shown). These results show that considerably more hair cell loss was achieved upon DT treatment in vitro than in vivo, but a small fraction of hair cells was retained in vitro, even following treatment with very high DT doses.

Some hair cells are replaced in the lateral extrastriolar region of the utricle

To examine whether utricular hair cells are replaced after DT treatment, adult Pou $4 \mathrm{f}^{+/ D T R}$ mice received two intramuscular injections of DT ( $1 \mu \mathrm{g}$ in $50 \mu \mathrm{l}$ saline) and were killed $21,28,40$, 60,90 , or 180 days post-DT (Fig. $3 A-E$ ). Between 14 and 28 days post-DT, numbers of myosin VIIa + (hair) cells increased about twofold $(p=0.04)$, and between 28 and 60 days it increased another 1.6 -fold ( $p=0.001$ ). At 60 days post-DT, hair cell numbers were $17 \%$ of untreated Pou $43^{+/ D T R}$ mice (compared to $6 \%$ of untreated Pou $43^{+/ D T R}$ mice at 14 days). The number of replacement hair cells decreased between 60 and 90 days post-DT to $13 \%$ of untreated Pou $43^{+/ D T R}$ mice $(p=0.022)$, but was not significantly changed between 90 and 180 days.

Replacement hair cells had a consistent distribution at 28 days post-DT and later; they were most concentrated in the presumed lateral extrastriolar region and were relatively sparse in the other regions (Fig. 3C-E).

Replacement hair cells have short stereociliary bundles, multipolar shapes, and innervation characteristic of type II hair cells

The early decrease and subsequent increase in the number of myosin VIIa + cells suggested that original hair cells were lost and new hair cells were formed. If new hair cells were indeed differentiating, one would expect to see hair cells with immature morphologies emerge and acquire more developed features over time. Mature vestibular hair cells have a columnar cell body and an apical bundle of stereocilia that is organized in a staircase config- 
uration. During hair cell regeneration in birds, newly formed hair cells have an elongated cell body with one descending cytoplasmic process (Steyger et al., 1997; Stone and Rubel, 2000), an apical bundle of uniformly short stereocilia, and a concentrically located kinocilium (Cotanche, 1987). These features of early regenerating hair cells closely resemble developing hair cells (Cotanche and Sulik, 1984; Mbiene et al., 1984; Whitehead and Morest, 1985; DenmanJohnson and Forge, 1999). Over time, avian hair cells attain mature shapes, the individual rows of stereocilia elongate differentially to achieve a staircase pattern, and the kinocilium moves to a peripheral location within the bundle (Cotanche, 1987).

We analyzed phalloidin-labeled stereociliary bundles on myosin VIIa + hair cells in adult Pou $43^{+/ D T R}$ mice after DT treatment. At all times, hair cells with long bundles typical of original mature hair cells were present (Fig. $4 A-F, H$ ) and were distributed throughout the sensory epithelium (Fig. 4A-C). However, the percentage of hair cells that had long bundles decreased significantly over time $(p<0.0001)$ (Fig. $4 H)$. At 7 days postDT, $90 \%$ of hair cells had long bundles; at 60 days, $11 \%$ of hair cells had long bundles; and at 180 days, 3\% had long bundles.

Hair cells lacking phalloidin-labeled stereocilia were also distributed throughout the sensory epithelium (Fig. 4D, $H$ ). Such cells were either damaged hair cells that had lost their bundles or replacement hair cells that had not yet formed bundles. The percentage of hair cells with no bundle was very low at 7 days post-DT (9\%). By 14 days, it had increased to $32 \%$. By 90 days, only $8 \%$ of hair cells lacked a bundle. ANOVA demonstrated a significant effect of time on the percentage of hair cells with no bundle $(p=0.01)$.

Hair cells with short bundles (about one-third the length of long bundles) were also detected at all times (Fig. $4 E-H$ ). At 7 and 14 days post-DT, only a small percentage of hair cells ( 1 and $10 \%$, respectively) had this morphology. The percentage of hair cells with short bundles increased significantly over time $(p<0.0001)$, so that by 180 days, $88 \%$ of bundles had this morphology. At all times, hair cells with short bundles were concentrated in the lateral extrastriola. Some hair cells with short bundles had long kinocilia that were located on the outer edge of the bundle (Fig. $4 G)$, typical of a maturing hair cell.

These observations indicated that most original hair cells were lost rapidly after DT treatment, and additional hair cells continued to be lost over an extended period of time. The results also indicate that very few, if any, replacement hair cells acquired long bundles.

We also examined the shapes of myosin VIIa+ cells (hair cells). At 14 days post-DT, most remaining hair cells were round or oval (Fig. $5 A, A^{\prime}$ ). However, a few cells also had irregular shapes with one cytoplasmic process or several processes emanating from the soma (data not shown). Such "multipolar" cells predominated at all later times (Fig. $5 B-C^{\prime}$ ). Processes appeared to extend horizontally above the layer of the supporting cell nuclei (Fig. 5D). Hair cells with short bundles (the presumed replacement hair cells) consistently had well defined processes, while hair cells with long bundles (the presumed surviving original hair cells) were consistently round and lacked processes (Fig. $\left.5 B-C^{\prime}\right)$. Of 965 hair cells analyzed in 6 utricles at 90 days post-DT, 885 cells had a short bundle and processes, 3 cells had a long bundle and processes, 8 cells had a short bundle and no processes, and 69 had a long bundle and no processes. A Fisher's exact test of independence revealed that bundle length was strongly predictive of cell shape $(p<0.0001)$. As late as 180 days post-DT, most hair cells in the utricle still had short bundles and cytoplasmic pro- 


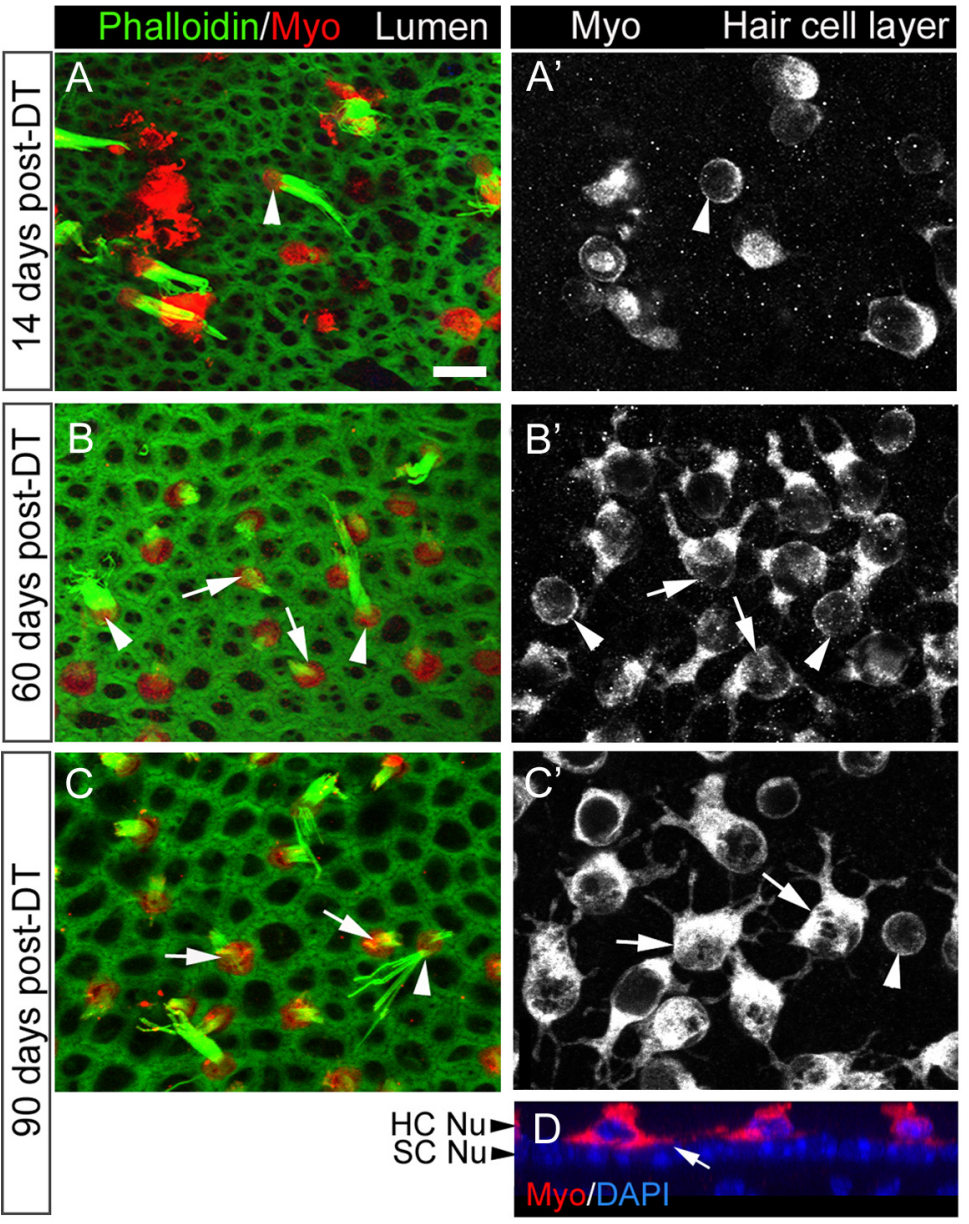

Figure 5. Shapes of replacement hair cells following DT treatment. $A-C^{\prime}$, Three sets of confocal slices taken near the lumenal surface in the presumed lateral extrastriola $(A, B, C$, labeled for phalloidin and myosin Vlla or Myo) or at the level of the hair cell bodies $\left(\boldsymbol{A}^{\prime}, \boldsymbol{B}^{\prime}, \boldsymbol{C}^{\prime}\right.$, labeled for Myo). $\boldsymbol{A}, \boldsymbol{A}^{\prime}$, The same field at 14 days post-DT. $\boldsymbol{B}, \boldsymbol{B}^{\prime}$, The same field at 60 days post-DT. $\boldsymbol{C}, \boldsymbol{C}^{\prime}$, The same field at 90 days post-DT. Arrowheads point to cells with long bundles and round cell bodies (presumed original hair cells), while arrows point to cells with short bundles and multipolar cell bodies (presumed replacement hair cells). $\boldsymbol{D}$. Vertical slice through the presumed lateral extrastriola at 90 days post-DT, illustrating the location of the hair cell processes above the supporting cell nuclear layer ( $\mathrm{SC} \mathrm{Nu}$ ). $\mathrm{HC} \mathrm{Nu}$, Hair cell nuclear layer. Scale bar (in $\boldsymbol{A}) \boldsymbol{A}-\boldsymbol{D}, 6 \mu \mathrm{m}$. support our interpretations from confocal microscopic analyses that hair cells are lost from the utricle by 14 days post-DT, and there is some hair cell replacement by 60 days post-DT.

\section{Replacement hair cells appear to have active mechanotransduction channels}

The majority of replacement hair cells in adult Pou $4 \mathrm{f3}^{+/ D T R}$ mice after DT treatment have short bundles of stereocilia and cytoplasmic processes (Figs. 4, 5), which reflect an immature phenotype. To address this, we tested whether such cells were capable of rapidly incorporating the styrl dye FM1-43. Rapid FM1-43 uptake has been linked with the maturation of mechanotransduction channels in hair cells (Gale et al., 2001; Meyers et al., 2003; Si et al., 2003). We isolated utricles from Pou $43^{+/ D T R}$ mice at 80 days post-DT, when numerous replacement hair cells with short stereocilia would be present, and exposed them to FM1-43 for $1 \mathrm{~min}$. We performed identical experiments in wild-type utricles. In wild-types, FM1-43 fluorescence was seen in many hair cells (Fig. $8 A-C$ ), but was not seen in supporting cells (data not shown). In Pou $43^{+/ D T R}$ utricles at 80 days post-DT, rapid FM1-43 uptake occurred in many replacement hair cells with short bundles (Fig. 8D-F). These results indicate that, although most replacement hair cells have an immatureappearing bundle and an unusual shape, they appear to have functional mechanotransduction channels based on their rapid uptake of FM1-43. cesses (not shown). These observations strongly suggest that this unusual morphology was a stable end-point among replacement hair cells.

Replacement hair cells (with short bundles and cytoplasmic processes) were never surrounded by the large calyceal nerve endings characteristic of type I hair cells (Fig. 6A, $A^{\prime}$ ). They were clearly associated with discrete patches of immunolabeling for Ctbp2 (C-terminal binding protein 2), a protein associated with ribbon synapses (Schug et al., 2006) (Fig. 6B,C). These observations suggest that replacement hair cells are type II-like and have synaptic elements.

\section{Hair cell replacement is evident in sectioned utricles}

In addition to using molecular markers for hair cells, we assessed hair cell loss and replacement in semi-thin plastic sections of adult mouse utricles. In wild-type mice at 14 days post-DT, hair cells appeared normal (Fig. 7A), with relatively long stereocilia (inset). In Pou $4 \mathrm{f3}^{+/ D T R}$ mice at 14 days post-DT (Fig. $7 B$ ), nearly all hair cells had been extruded from the epithelium and only supporting cell nuclei remained. In Pou $4 \mathrm{f}^{+/ D T R}$ mice at 60 days post-DT (Fig. 7C), hair cell profiles had reemerged, some of which had clear short stereocilia (Fig. 7C, inset). These findings
Replacement hair cells are formed by direct

transdifferentiation of supporting cells into hair cells

One interpretation of the loss and subsequent reappearance of hair cells is that they are being regenerated. In nonmammalian vertebrates, nonsensory cells in the sensory epithelium (presumed supporting cells) serve as progenitors for new hair cells using two mechanisms (for review, see Stone and Cotanche, 2007). Some cells phenotypically convert into hair cells without an intervening mitosis (a process called direct transdifferentiation). Other cells divide, and their daughter cells differentiate into hair cells or supporting cells. In addition, some injured hair cells are capable of recovery (Gale et al., 2002).

We performed several experiments to determine whether new hair cells are indeed formed in adult mice after DT treatment. First, we examined whether any replacement hair cells were derived from supporting cell division. Adult Pou $4 \mathrm{f}^{+/ D T R}$ mice were provided with drinking water containing the mitotic tracer BrdU for different 7 day periods after DT treatments (0-7 days, 8-14 days, 5-21 days, 22-28 days, or 53-60 days). At the end of the treatment period, mice were killed and utricles were fixed and immunolabeled for BrdU. Although numerous BrdU+ nuclei were detected in the connective tissue underlying the sensory epithelium, BrdU- 
labeled cells were rarely seen in the sensory epithelium at any times examined (examples are shown in Fig. 9A$\left.B^{\prime}\right)$. At maximum, one cell per utricle was seen, and such cells were always myosin VIIa-. Similar observations were made in Pou $43^{+/ D T R}$ mice that received a single intraperitoneal injection of BrdU per day on days $0-7$ post-DT (not shown). These observations suggest that supporting cell division is a rare event and therefore an unlikely mechanism by which significant numbers of hair cells are replaced in Pou $43^{+/ D T R}$ mice after DT treatment.

Next, we tested the hypothesis that supporting cells directly convert into hair cells by assessing whether they upregulate the hair cell-specific transcription factor Atoh1. Utricles were explanted from Pou $43^{+/ D T R}$ mice at 7, 14, and 28 days after DT administration in vivo and cultured overnight with an Atoh1 reporter virus, Ad5-Atoh1-GFP. Utricles were cultured for 5 more days in virus-free media and then fixed and immunolabeled for GFP and myosin VIIa. Utricles from untreated wild-types, which received no DT treatment, were cultured identically. Ad5 transduces $~ 27 \%$ of supporting cells (about 1,000 cells per organ) in undamaged utricles from adult mice in vitro (Lin et al., 2011). Similar rates were noted in utricles 7 days after neomycin-induced hair cell damage in vitro, suggesting that hair cell loss does not significantly alter transduction efficiency (data not shown). Numbers of Atoh1-GFP+ cells were very low in the sensory epithelium of utricles from untreated wild-types and from Pou $43^{+/ D T R}$ mice at 7 days post-DT, but in Pou $43^{+/ D T R}$ mice at 14 days post-DT, numbers had increased significantly $(p<.05)$ (Fig. 9C- $\left.E^{\prime}\right)$. Some Atoh1$\mathrm{GFP}+$ cells were myosin VIIa-, characteristic of supporting cells (Fig. 9D-E'), and some were myosin $\mathrm{VIIa}+$, similar to hair cells (Fig. $\left.9 C-E^{\prime}\right)$. Numbers of Atoh1-GFP+/myosin VIIa + cells were significantly higher in Pou $4 \mathrm{f3}^{+/ D T R}$ utricles at 14 days than in Pou $4 \mathrm{f3}^{+/ D T R}$ mice at 7 days or in untreated wild-type mice. There was no significant change in the numbers of Atoh1-GFP + cells or Atoh1-GFP+/ myosin VIIa + cells in Pou $43^{+/ D T R}$ mice between 14 and 28 days post-DT, but there was substantial variation in the number of Atoh1-GFP+ cells in these groups for reasons that are unclear. These results demonstrate that DT-induced hair cell damage triggers significant upregulation of Atoh1 transcriptional activity in supporting cells and differentiating hair cells after damage and before the emergence of replacement hair cells.

If significant numbers of supporting cells were converting into hair cells without dividing, then one would expect their numbers to be substantially decreased in regions where, and at times when, hair cells are being replaced. To test this hypothesis, we estimated supporting cell numbers in utricles from Pou $43^{+/ D T R}$ mice at 14, 40, 60, 90 , and 180 days post-DT. We also examined supporting cell numbers in three groups of controls: Pou $43^{+/ D T R}$ mice without DT treatment, wild-type mice without DT treatment, and wild-type mice at 14 days post-DT. Average numbers $( \pm S D)$ are graphed in Figure $10 \mathrm{~A}$. We found no significant differences in supporting cell numbers

\section{Pou4f3 ${ }^{+/ D T R} 180 \mathrm{~d}$ pDT}
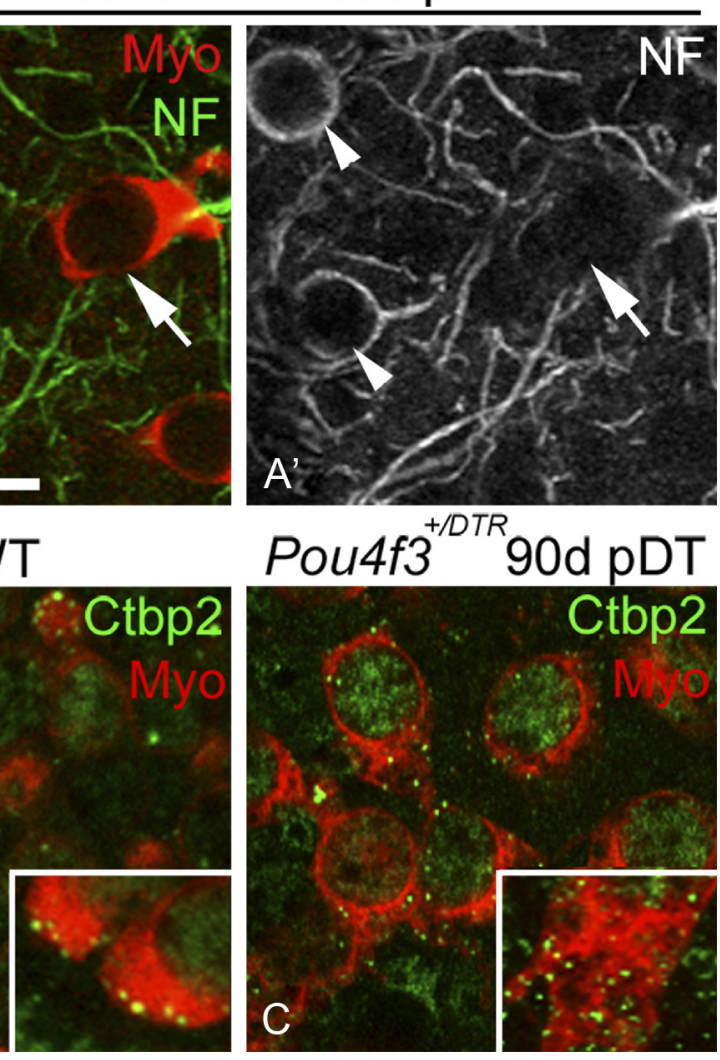

Neural elements associated with replacement hair cells. $\boldsymbol{A}, \boldsymbol{A}^{\prime}$, Confocal slices from the presumed lateral extrastriol and a Pou4f3 ${ }^{+/ D T R}$ mouse at 90 days post-DT (C). Myosin Vlla labeling is red and Ctbp2 labeling is green. Insets show the basal portion of exemplary hair cells at higher magnification. Scale bar: (in $\boldsymbol{A}) \boldsymbol{A}-\boldsymbol{C}, 6 \mu \mathrm{m}$.

among the three control groups $(p>0.05)$. These results suggested that supporting cells developed normally in transgenic mice and that wild-type supporting cells were not damaged by DT treatments. In Pou $4 \mathrm{f}^{+/ D T R}$ mice at 14 days post-DT, supporting cell numbers were significantly reduced compared to wild-type mice at 14 days post-DT $(p=0.002)$ and compared to Pou $43^{+/ D T R}$ mice that received no DT treatments $(p=0.003)$. In Pou $43^{+/ D T R}$ mice, supporting cell numbers decreased significantly between 14 and 60 days post-DT ( $p=0.0003)$, but they did not change significantly after 60 days $(p>0.05)$. Overall, supporting cell numbers declined as hair cell numbers increased to a similar degree and with similar timing (compare Figs. 10A and $3 A$ ). Loss of supporting cell density and expansion of supporting cell apical surfaces appeared to be most pronounced in the presumed lateral extrastriola, where the most hair cell replacement occurred (Fig. $10 B-C^{\prime}$ ). Collectively, these observations strongly suggest that supporting cells are converting directly into hair cells and are not being rapidly replaced by supporting cell division following DT-mediated hair cell damage.

\section{Discussion}

We developed a line of mice to enable temporally controlled and selective ablation of hair cells in vivo. In adult utricles, nearcomplete hair cell loss was achieved in 2 weeks. Approximately $17 \%$ of hair cells were restored by 2 months. Replacement hair cells had short stereociliary bundles and were type-II like, as de- 


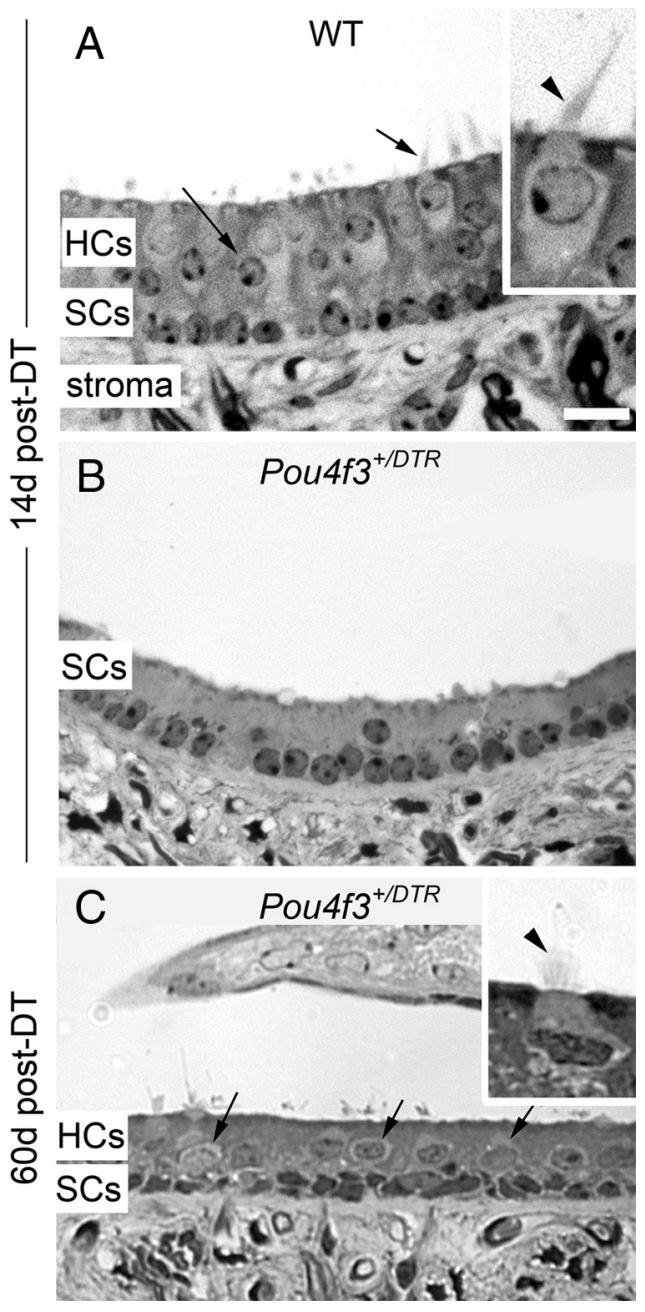

Figure 7. Hair cell loss and replacement are evident in sectioned utricles. A-C, Crosssections through the presumed lateral extrastriola of utricles from a wild-type (WT) mouse at 14 days (d) post-DT $(\boldsymbol{A})$, a Pou $4 f 3^{+/ D T R}$ mouse at 14 days post-DT $(\boldsymbol{B})$, and a Pou $43^{+/ D T R}$ mouse at 60 days post-DT (C). The hair cell layer (HCs) and supporting cell layer (SCS) are indicated, as is the stromal layer (stroma). Arrows in $\boldsymbol{A}$ and $\boldsymbol{C}$ point to hair cells. Insets in $\boldsymbol{A}$ and $\boldsymbol{C}$ show exemplary hair cells at higher magnification, with arrowheads indicating the stereociliary bundle in each cell. Scale bar (in $\boldsymbol{A}) \boldsymbol{A}-\boldsymbol{C}, 12 \mu \mathrm{m} ; \boldsymbol{A}$ and $\boldsymbol{C}$ insets, $6 \mu \mathrm{m}$.

scribed before. We made several new observations. Replacement hair cells were confined to the presumed lateral extrastriolar region. They had unusual cytoplasmic processes, yet they possessed properties of mature hair cells. Further, supporting cells upregulated Atoh1 transcriptional activity, suggesting they transdifferentiated into new hair cells.

\section{The Pou $4 \mathrm{f3}^{\text {DTR }}$ mouse enables near-total hair cell ablation in adult utricles}

Mice are excellent animals for studies of hair cell regeneration due to their capacity for targeted genetic manipulation. An ideal method for hair cell destruction in regeneration studies would: (1) induce rapid and synchronized destruction of all hair cells; (2) show efficacy in adult mice; (3) have negligible effects on other inner ear cells; (4) be rapid and easy to implement; and (5) induce limited illness. The first two characteristics are particularly important. Complete loss of original hair cells enables distinction of regenerated hair cells from repaired hair cells. Examination of adult mice is preferred because the developing ear exhibits considerable plasticity that is absent in maturity (Gu et al., 2007;
Doetzlhofer et al., 2009). Furthermore, mature humans are critical targets for future therapies. The most commonly used method for inducing hair cell loss-systemic administration of aminoglycosides - is very toxic and causes limited hair cell loss in adult mice, posing significant disadvantages for regeneration studies.

To generate an improved damage method in mice, we engineered a transgenic mouse $\left(P o u 4 f 3^{+/ D T R}\right)$ that enables precisely timed and selective ablation of hair cells. The human diphtheria toxin receptor (DTR) gene was placed under control of the mouse Pou4f3 gene, whose expression in the inner ear is limited to hair cells. Administration of diphtheria toxin to adult Pou $43^{+/ D T R}$ mice killed $94 \%$ of hair cells in the adult mouse utricle within 2 weeks, with no apparent toxicity in supporting cells. Similar results were obtained in the cochlea (Tong et al., 2011) and will be described in subsequent reports. In mature Pou $4 \mathrm{f}^{+/ D T R}$ mice, DT caused transient vestibulomotor deficits that usually resolved within 1 week. These effects were absent in wild-type mice. The specific cause for these symptoms is unclear. Because Pouff3 is expressed in other tissues, deficits could have been caused by DT-driven cell loss outside of the inner ear. We hypothesize that the rapid abatement of symptoms was due to CNS compensation rather than hair cell regeneration, because regeneration lagged recovery by a few weeks.

Some hair cells with long bundles (presumed original hair cells) were not rapidly killed by DT treatment, either in vivo or in vitro. One possibility is that these hair cells were not exposed to lethal levels of DT. We doubt this, because: (1) a single molecule of DT is sufficient to induce cell death (Yamaizumi et al., 1978); (2) the same dosing regimen of DT in vivo kills every hair cell in the cochlea within a week (Tong et al., 2011); and (3) culture conditions should provide maximal DT exposure to hair cells. An alternative explanation is that DT was more slowly metabolized in some hair cells than others, delaying toxicity. DT has two subunits that enter the cell through endosomes (Chenal et al., 2002). DT-B binds the receptor, and DT-A (the toxin) enters the cytoplasm and blocks translation. Retention of the toxin in the endosomal compartment could delay toxicity. A third explanation is that a few mature hair cells had very low Pou $4 f 3$ expression (and therefore $h u D T R$ expression) and were therefore unresponsive to low DT doses. While many hair cells in the mature organ of Corti are immunoreactive for POU4F3 protein (Xiang et al., 1997), it is not clear whether Pou 43 is expressed in all hair cells in the adult mouse utricle. Further studies are required to assess why a small number of hair cells are spared after DT treatment.

\section{Comparison with other transgenic mouse models for hair cell ablation}

At least two additional transgenic mice have been used to ablate hair cells in the inner ear. Using inducible Cre/lox technology, Burns et al. (2012) generated a mouse line expressing DT-A only in cells with Atoh 1 enhancer activity and only upon tamoxifen treatment. Partial $(28-50 \%)$ loss of hair cells was achieved in neonatal utricles, most likely because of downregulation of both Atoh1-driven Cre activity (Burns et al., 2012) and Atoh1 transcription (Shailam et al., 1999) shortly after birth. Accordingly, tamoxifen should not cause significant hair cell loss in adult utricles, but Burns et al. (2012) did not examine this age group. They did find that hair cell ablations in neonatal utricles triggered substantial cell division and that many post-mitotic cells differentiated into hair cells. These observations contrast sharply with our finding that little mitotic regeneration of hair cells occurred in adult mice. Most likely, this discrepancy is due 


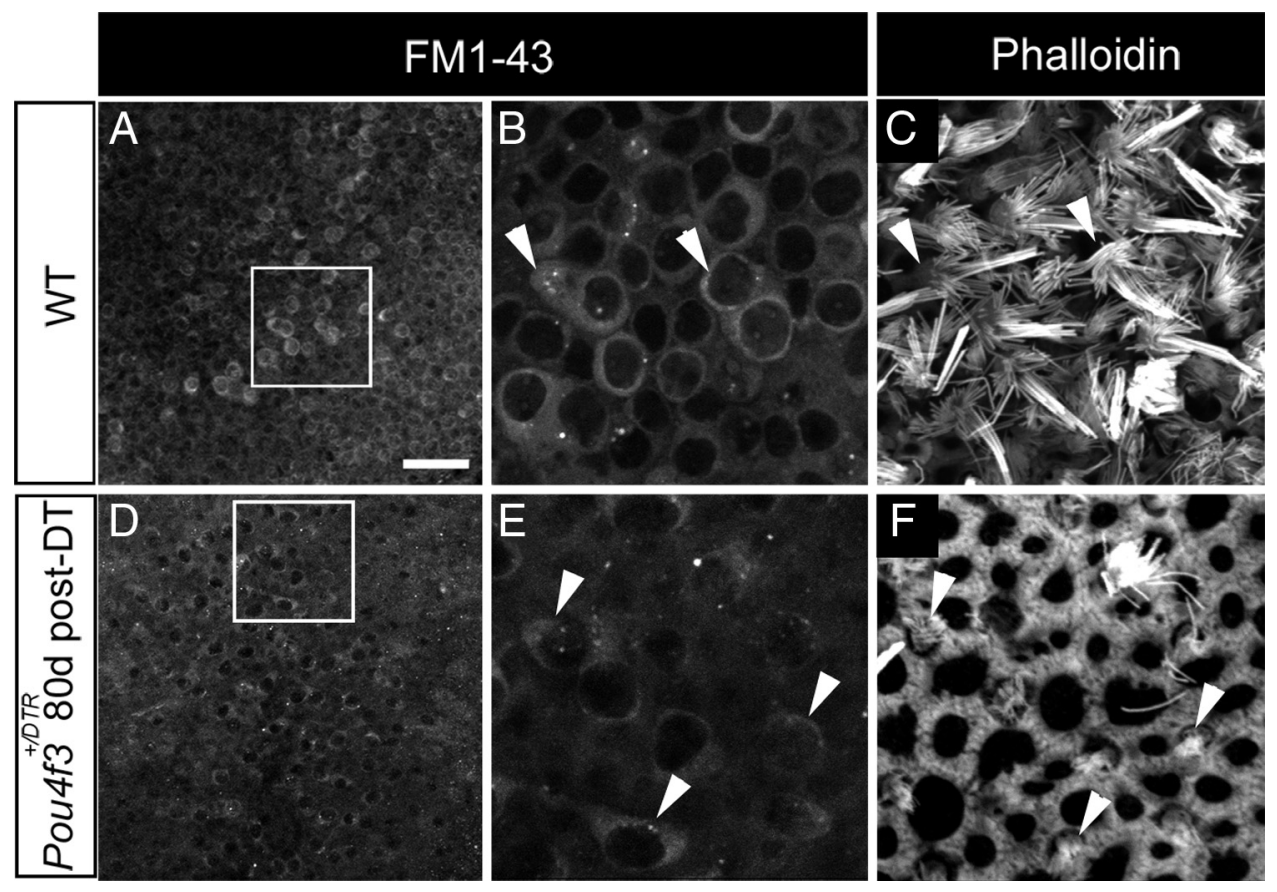

Figure 8. Replacement hair cells rapidly incorporate FM1-43.A, D. FM1-43 signal in utricles from a wild-type (WT) mouse (A) and a Pou4f3 ${ }^{+/ D T R}$ mouse at 80 days post-DT (D). $\boldsymbol{B}, \boldsymbol{E}$, The boxed regions in $\boldsymbol{A}$ and $\boldsymbol{D}$ are shown at higher magnification in $\boldsymbol{B}$ and $\boldsymbol{E}$, respectively. $\boldsymbol{C}, \boldsymbol{F}$, Phalloidin labeling in the same fields as shown in $\boldsymbol{B}$ and $\boldsymbol{E}$ but at the level of hair cell stereocilia. Hair cells with long stereociliary bundles in WT utricles ( $\boldsymbol{B}, \boldsymbol{C}$, arrowheads) take up FM1-43. Hair cells with short stereociliary bundles in Pou4f3 ${ }^{+/ D T R}$ utricles ( $\boldsymbol{E}, \boldsymbol{F}$, arrowheads) also take up FM1-43. Scale bar (in $\left.\boldsymbol{A}\right) \boldsymbol{A}, \boldsymbol{D}, 25 \mu \mathrm{m} ; \boldsymbol{B}, \boldsymbol{C}, \boldsymbol{E}, \boldsymbol{F}, 8 \mu \mathrm{m}$.
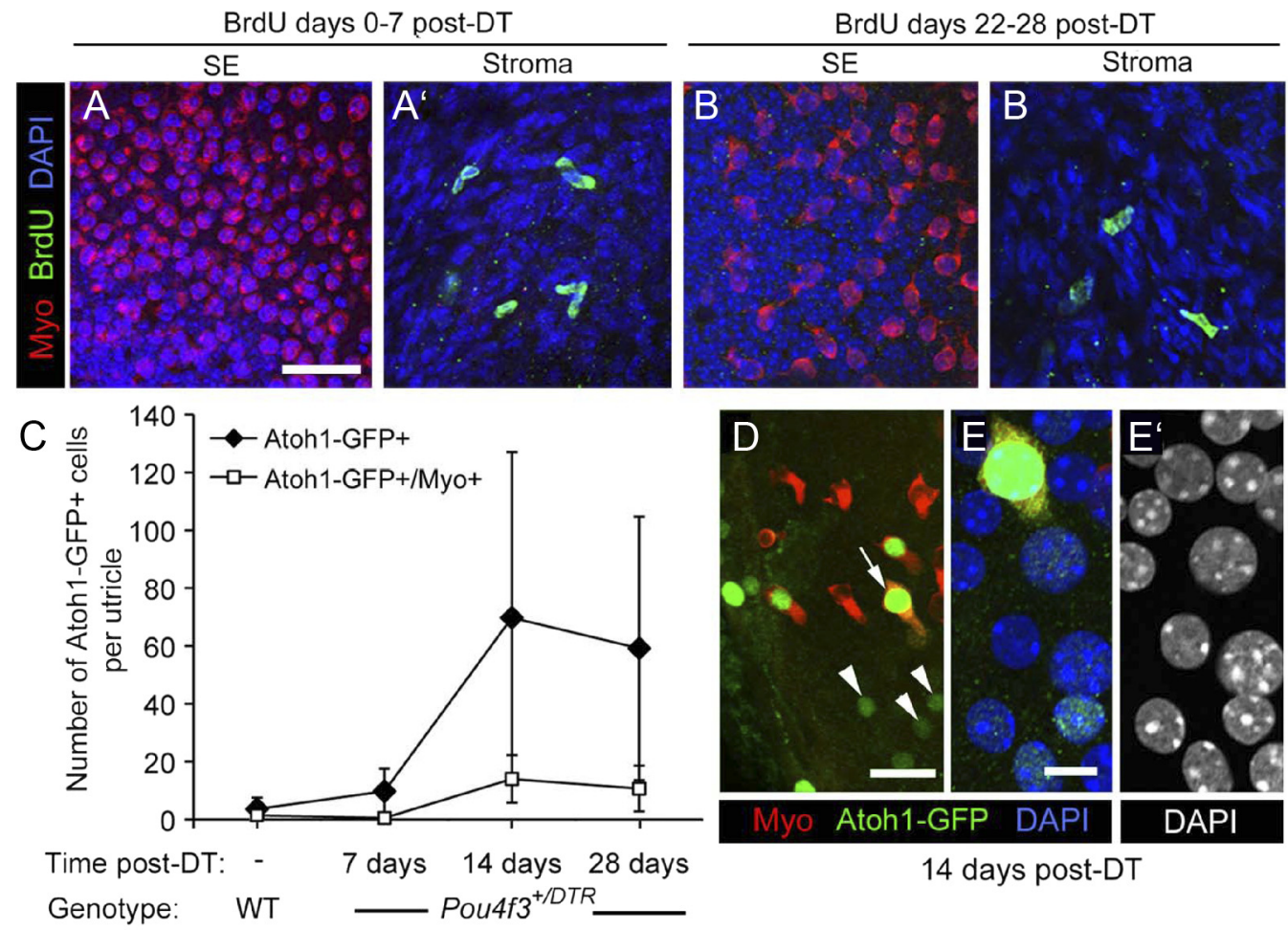

Time post-DT: - 7 days 14 days 28 days
Genotype: WT $\quad$ Pou $4 f 3^{+/ D T R}$

14 days post-DT

Experimental groups

Figure 9. In the absence of supporting cell division, Atoh1 is transcriptionally activated in DT-treated utricles. $\boldsymbol{A}-\boldsymbol{B}^{\prime}$, BrdU labeling in damaged utricles. Virtually no BrdU uptake was seen in the sensory epithelium (SE) in Pou4f3 ${ }^{+/ D T R}$ utricles after DT treatment. Confocal images show the utricular sensory epithelium (SE) or stroma from Pou4f3 ${ }^{+/ D T R}$ mice that received BrdU between 0 and 7 days post-DT ( $A$, $\boldsymbol{A}^{\prime}$ ) or between 22 and 28 days post-DT $\left(\boldsymbol{B}, \boldsymbol{B}^{\prime}\right)$. Myosin Vlla (Myo) labeling is shown in red, BrdU labeling is in green, and DAPI (nuclear) labeling is in blue. $\boldsymbol{C}-\boldsymbol{E}^{\prime}$, Atoh1 transcriptional activity in the damaged utricle. $C$, Graph of the mean number of Atoh1-GFP + and Atoh1-GFP +/myosin Vlla + cells per utricle $( \pm$ SD) for the following experimental groups: uninjected $(-)$ wild-types (WT) $(n=5$ utricles) and Pou4f3 ${ }^{+/ D T R}$ mice at 7 days post-DT (4 utricles), 14 days post-DT (4 utricles), and 28 days post-DT ( 5 utricles). D, Atoh1-GFP + (green) nucleiat 14 days post-DT in cells that were either myosin VIlla + (arrow, red cytoplasm) or myosin VIla - (arrowheads). $\boldsymbol{E}, \boldsymbol{E}^{\prime}$, A higher magnification of the Atoh1-GFP +/myosin Vlla + cell indicated by the arrowin D. E, Labeling for Atoh1-GFP (green), myosin VIlla (red), and DAPI (blue). $\boldsymbol{E}^{\prime}$, DAPl used only to illustrate nuclear localization of the Atoh1-GFP in $\boldsymbol{E}$. Scale bar (in $\left.\boldsymbol{A}\right) \boldsymbol{A}-\boldsymbol{B}^{\prime}, 24 \mu \mathrm{m}$; (in $\boldsymbol{D}$ ), $10 \mu \mathrm{m}$; (in $\left.\boldsymbol{E}\right) \boldsymbol{E}, \boldsymbol{E}^{\prime}, 4 \mu \mathrm{m}$. 

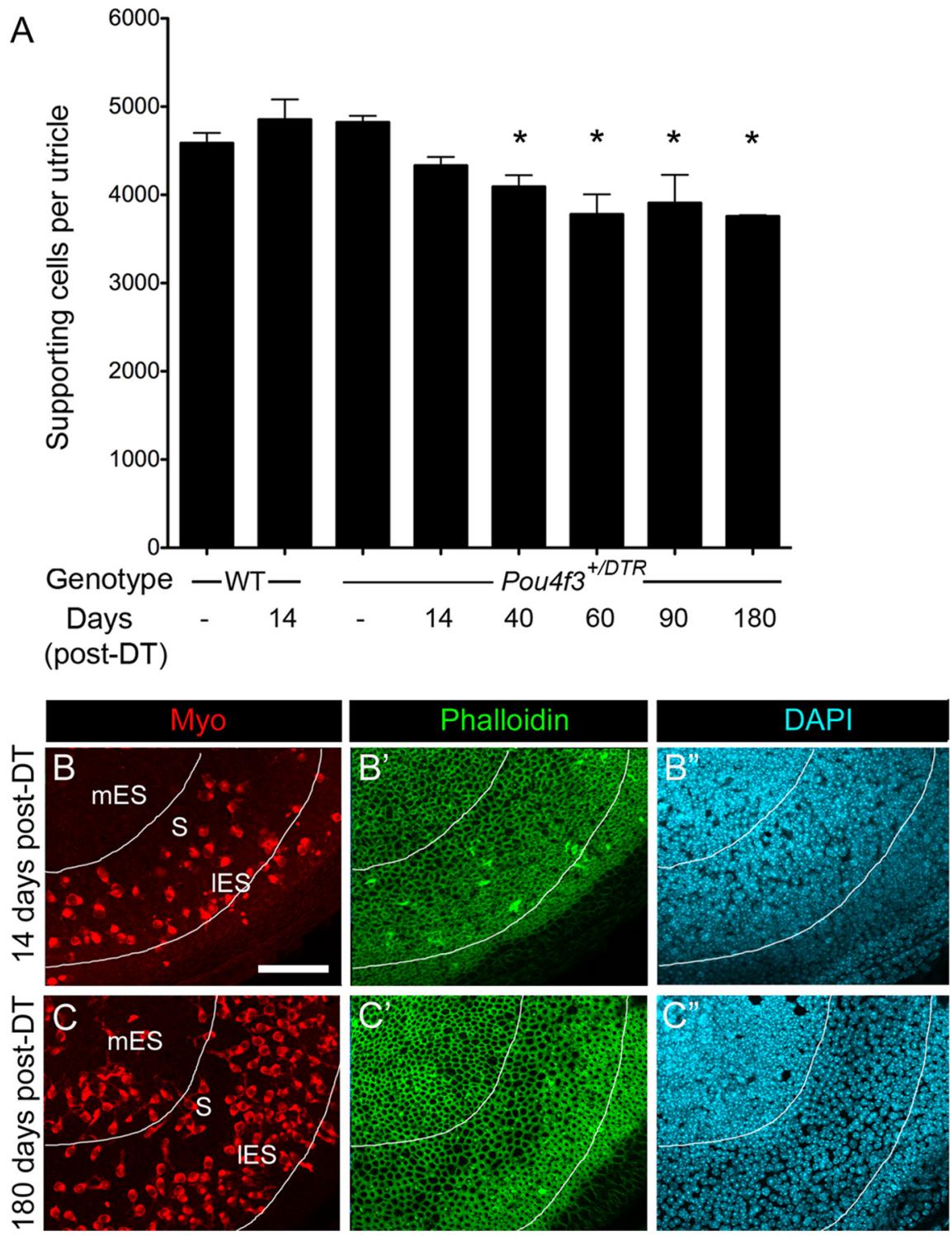

Figure 10. Supporting cell densities decline as hair cells are replaced. $A$, Graph of average number of supporting cells per utricle ( \pm SD) in uninjected $(-)$ WT mice, WT mice at 14 days post-DT, uninjected $(-)$ Pou4f3 ${ }^{+/ D T R}$ mice, and Pou4f3 ${ }^{+/ D T R}$ mice at several times post-DT. Sample numbers for counts are provided in Table 1. Asterisks denote values that are significantly different from those of uninjected wild-typemice (ANOVA, Fisher's PLSD; $\boldsymbol{p}<.05$ ). $\boldsymbol{B}-\boldsymbol{C}^{\prime}$, Confocal slices of Pou4f3 ${ }^{+/ D T R}$ mouse utricles at 14 days post-DT $\left(\boldsymbol{B}-\boldsymbol{B}^{\prime \prime}\right)$ and at 180 days post-DT ( $\boldsymbol{C} \boldsymbol{C}^{\prime}$ ) labeled for myosin Vlla (Myo), phalloidin, and DAPI. The same field is shown in $\boldsymbol{B}-\boldsymbol{B}^{\prime \prime}$ and in $\boldsymbol{C}-\boldsymbol{C}^{\prime}$ with $\boldsymbol{B}, \boldsymbol{B}^{\prime}, \boldsymbol{C}$, and $\boldsymbol{C}^{\prime}$ focused on the hair cell layer and $\boldsymbol{B}^{\prime \prime}$ and $\boldsymbol{C}^{\prime}$ focused on the supporting cell layer of each field. Note the apparent expansion of supporting cell surfaces $\left(\boldsymbol{C}^{\prime}\right)$ and decrease in supporting cell nuclear density $\left(\boldsymbol{C}^{\prime}\right)$ in the presumed striola/lateral extrastriola at 180 days relative to 14 days. The lines surround the region that shows supporting cell thinning at 180 days post-DT. mES, Medial extrastriola; $\mathrm{S}$, striola; IES, lateral extrastriola. Scale bar (in $\boldsymbol{B}) \boldsymbol{B}-\boldsymbol{C}^{\prime \prime}, 50 \mu \mathrm{m}$.

to the sharp reduction in the capacity of mammalian supporting cells to divide as utricles mature (Hume et al., 2003; Gu et al., 2007).

Fujioka et al. (2011) generated Pou4f3-Cre;Mos-iCsp3 mice that encode a form of the proapoptotic gene caspase 3. Caspase 3 becomes activated in some Pou $4 \mathrm{f3}$-expressing cells upon addition of a drug that induces caspase 3 dimerization. The authors induced apoptosis in a subpopulation of cochlear hair cells. The mosaic pattern was achieved due to a lox-mismatched Cre-lox system (Miller et al., 2008). Patterns of vestibular hair cell loss were not described. Using Pou $43^{D T R}$ mice, we found that hair cell ablation was nearly complete in vestibular and auditory hair cells. Future studies will address whether smaller hair cell lesions are achievable with lower DT doses.
Hair cells are replaced via direct transdifferentiation

Prior studies reported that hair cell profiles spontaneously re-emerge in mature rodent utricles after ototoxic drug treatment in vivo (Forge et al., 1993, 1998; Kawamoto et al., 2009). Forge et al. (1993, 1998) describe a nearly $70 \%$ recovery of hair cell numbers in the lesioned area (striola) of adult guinea pig utricles after gentamicin. Kawamoto et al. (2009) observed hair cell replacement in adult mice after gentamicin treatment. Very little division of supporting cells - the hair cell progenitors-occurs after hair cell damage in adult rodents (Forge et al., 1993, 1998; Rubel et al., 1995; Kuntz and Oesterle, 1998; Kawamoto et al., 2009). A small but significant reduction in supporting cell numbers happens as hair cells are replaced in guinea pig utricles (Forge et al., 1998).

We made similar observations in adult Pou $43^{+/ D T R}$ mouse utricles following induction of near-complete hair cell loss by DT in vivo using molecular markers for hair cells. Hair cell numbers tripled between 14 and 60 days post-DT, increasing from 6 to $17 \%$ of normal. Replacement hair cells were not formed via supporting cell division, but there was a significant decrease in supporting cell numbers that mirrored the increase in hair cell numbers quantitatively, spatially, and temporally. Further, we found that transcriptional activity of Atoh1, a gene driving hair cell differentiation, was upregulated in supporting cells and in replacement hair cells after DT treatment and before the significant increase in hair cell numbers in vivo. This finding adds exceptionally strong support for the hypothesis that a small number of supporting cells activate a hair cell-like transcriptional program after DTmediated hair cell loss in vivo and transdifferentiate into hair cells without dividing. In a recent paper, we showed definitively by using cell fate mapping that some supporting cells in cultured adult mouse utricles activate Atoh1 after aminoglycoside treatment and convert into hair cell-like cells (Lin et al., 2011).

Properties of replacement hair cells

Nearly all hair cells that were replaced in mouse utricles after DT-mediated hair cell destruction had very short bundles and lacked calyceal endings, and were therefore type II-like (Desai et al., 2005; Li et al. 2008). Similar observations have been made in adult rodent utricles after ototoxic drug treatment (Forge et al., 1993, Kawamoto et al., 2009). It is possible that some replacement hair cells in our study and in others were type I like but were not identified as such using our classification criterion (the presence of a calyx). Calyces might eventually form on some replace- 
ment cells with longer recovery periods (Weisleder and Rubel, 1993; Weisleder et al., 1995; Zakir and Dickman, 2006).

We made two new observations about hair cell replacement in vivo. First, replacement hair cells had an unusual morphology, with two or more processes extending from their cell body. We initially thought that this appearance might reflect arrest at an immature stage of differentiation. However, further analysis revealed that this appearance was stable over time (up to 180 days post-DT), and replacement hair cells had several mature features, including markers for ribbon synapses, eccentrically located kinocilia, and rapid FM1-43 uptake. We considered that the unusual morphology could have resulted from Pou 43 heterozygosity, but this is unlikely since normal-appearing hair cells developed in mice with one Pou4f3 allele. It is also unlikely that the unusual morphology was caused by continued DT toxicity. We saw few signs of hair cell demise (pyknotic nuclei, cellular fragmentation) after the initial period of hair cell death, suggesting DT toxicity was confined to shortly after treatment. Furthermore, DT-A is not toxic if released from a cell, since it cannot re-enter a cell without DT-B. Based on these interpretations, we conclude that either (1) replacement hair cells are mature and represent a morphological subtype that has not been described previously, or (2) replacement hair cells are mature but exhibit an abnormal phenotype due to unidentified changes that accompany severe hair cell loss.

The second new observation was that hair cell replacement was largely restricted to the presumed lateral extrastriola despite destruction of nearly all hair cells and long periods of recovery. This has not been described before in vivo, but a similar observation was made in adult mice after neomycin treatment in vitro (Lin et al., 2011). Inhibition of signaling through the notch receptor and other gamma secretase-dependent pathways did not stimulate hair cell replacement in other areas (Lin et al., 2011). Therefore, unidentified factors must promote or restrict regional hair cell replacement in adult mouse utricles.

\section{Is there regional hair cell turnover in adult mouse utricles?}

Most hair cells that were present shortly after DT treatment (14 days) were round and had a very short bundle or no bundle. These cells were concentrated in the presumed lateral extrastriola, which is the same region where, at later times, replacement hair cells with long cytoplasmic processes and a short bundle accumulated. These observations suggest that hair cells present at 14 days may be immature versions of the final replacement hair cells. Such cells would differentiate rapidly after DT treatment if they are derived from a pool of hair cell precursors that had not yet activated Pou 4 f3 expression when DT was administered. Undifferentiated precursors would reside in the lateral extrastriola of normal adult utricles if hair cells were continually added there. DT treatment would not harm such cells, and they would be allowed to acquire hair cell characteristics. If turnover does occur in a subpopulation of hair cells and this is the only population replaced after damage, this could explain why the new hair cells that we detected after DT treatment were limited in number, shared a particular morphology, and were regionally restricted.

It is well established that vestibular hair cells are continually replaced in birds (Jørgensen and Mathiesen, 1988; Roberson et al., 1992; Kil et al., 1997). Signs of cell turnover-hair cells with immature morphologies, low levels of cell division, and apoptotic cellshave been detected in undamaged utricles from mature rodents and bats (Forge et al., 1993, 1998; Rubel et al., 1995; Lambert et al., 1997; Kuntz and Oesterle, 1998; Kirkegaard and Jørgensen, 2000), but proof has not been provided. Further work is needed to determine whether some type II-like hair cells are indeed replaced on a regular basis in adult mouse utricles and if this process dictates the degree of hair cell replacement seen after damage.

\section{References}

Aran JM, Chappert C, Dulon D, Erre JP, Aurousseau C (1995) Uptake of amikacin by hair cells of the guinea pig cochlea and vestibule and ototoxicity: comparison with gentamicin. Hear Res 82:179-183. CrossRef Medline

Burns JC, Cox BC, Thiede BR, Zuo J, Corwin JT (2012) In vivo proliferative regeneration of balance hair cells in newborn mice. J Neurosci 32:65706577. CrossRef Medline

Chenal A, Nizard P, Gillet D (2002) Structure and function of diphtheria toxin: from pathology to engineering. J Toxicol Toxin Rev 21:321-359. CrossRef

Corwin JT, Cotanche DA (1988) Regeneration of sensory hair cells after acoustic trauma. Science 240:1772-1774. CrossRef Medline

Cotanche DA (1987) Regeneration of hair cell stereociliary bundles in the chick cochlea following severe acoustic trauma. Hear Res 30:181-195. CrossRef Medline

Cotanche DA, Sulik KK (1984) The development of stereociliary bundles in the cochlear duct of chick embryos. Brain Res 318:181-193. CrossRef Medline

Cunningham LL, Cheng AG, Rubel EW (2002) Caspase activation in hair cells of the mouse utricle exposed to neomycin. J Neurosci 22:8532-8540. Medline

Denman-Johnson K, Forge A (1999) Establishment of hair bundle polarity and orientation in the developing vestibular system of the mouse. J Neurocytol 28:821-835. CrossRef Medline

Desai SS, Zeh C, Lysakowski A (2005) Comparative morphology of rodent vestibular periphery. I. Saccular and utricular maculae. J Neurophysiol 93:251-266. CrossRef Medline

Doetzlhofer A, Basch ML, Ohyama T, Gessler M, Groves AK, Segil N (2009) Hey2 regulation by FGF provides a Notch-independent mechanism for maintaining pillar cell fate in the organ of Corti. Dev Cell 16:58-69. CrossRef Medline

Erkman L, McEvilly RJ, Luo L, Ryan AK, Hooshmand F, O’Connell SM, Keithley EM, Rapaport DH, Ryan AF, Rosenfeld MG (1996) Role of transcription factors Brn-3.1 and Brn-3.2 in auditory and visual system development. Nature 381:603-606. CrossRef Medline

Forge A, Schacht J (2000) Aminoglycoside antibiotics. Audiol Neurootol 5:3-22. CrossRef Medline

Forge A, Li L, Corwin JT, Nevill G (1993) Ultrastructural evidence for hair cell regeneration in the mammalian inner ear. Science 259:1616-1619. CrossRef Medline

Forge A, Li L, Nevill G (1998) Hair cell recovery in the vestibular sensory epithelia of mature guinea pigs. J Comp Neurol 397:69-88. CrossRef Medline

Fujioka M, Tokano H, Fujioka KS, Okano H, Edge AS (2011) Generating mouse models of degenerative diseases using Cre/lox-mediated in vivo mosaic cell ablation. J Clin Invest 121:2462-2469. CrossRef Medline

Gale JE, Marcotti W, Kennedy HJ, Kros CJ, Richardson GP (2001) FM1-43 dye behaves as a permeant blocker of the hair-cell mechanotransducer channel. J Neurosci 21:7013-7025. Medline

Gale JE, Meyers JR, Periasamy A, Corwin JT (2002) Survival of bundleless hair cells and subsequent bundle replacement in the bullfrog's saccule. J Neurobiol 50:81-92. CrossRef Medline

Gu R, Montcouquiol M, Marchionni M, Corwin JT (2007) Proliferative responses to growth factors decline rapidly during postnatal maturation of mammalian hair cell epithelia. Eur J Neurosci 25:1363-1372. CrossRef Medline

Helms AW, Abney AL, Ben-Arie N, Zoghbi HY, Johnson JE (2000) Autoregulation and multiple enhancers control Math1 expression in the developing nervous system. Development 127:1185-1196. Medline

Heydt JL, Cunningham LL, Rubel EW, Coltrera MD (2004) Round window gentamicin application: an inner ear hair cell damage protocol for the mouse. Hear Res 192:65-74. CrossRef Medline

Hume CR, Kirkegaard M, Oesterle EC (2003) ErbB expression: the mouse inner ear and maturation of the mitogenic response to heregulin. J Assoc Res Otolaryngol 4:422-443. CrossRef Medline

Jørgensen JM, Mathiesen C (1988) The avian inner ear: continuous production of hair cells in vestibular sensory organs, but not in the auditory papilla. Naturwissenschaften 75:319-320. CrossRef Medline 
Kawamoto K, Izumikawa M, Beyer LA, Atkin GM, Raphael Y (2009) Spontaneous hair cell regeneration in the mouse utricle following gentamicin ototoxicity. Hear Res 247:17-26. CrossRef Medline

Kil J, Warchol ME, Corwin JT (1997) Cell death, cell proliferation, and estimates of hair cell life spans in the vestibular organs of chicks. Hear Res 114:117-126. CrossRef Medline

Kirkegaard M, Jørgensen JM (2000) Continuous hair cell turnover in the inner ear vestibular organs of a mammal, the Daubenton's bat (Myotis daubentonii). Naturwissenschaften 87:83-86. CrossRef Medline

Kirkegaard M, Nyengaard JR (2005) Stereological study of postnatal development in the mouse utricular macula. J Comp Neurol 492:132-144. CrossRef Medline

Kuntz AL, Oesterle EC (1998) Transforming growth factor alpha with insulin stimulates cell proliferation in vivo in adult rat vestibular sensory epithelium. J Comp Neurol 399:413-423. CrossRef Medline

Lambert PR, Gu R, Corwin JT (1997) Analysis of small hair bundles in the utricles of mature guinea pigs. Am J Otol 18:637-643. CrossRef Medline

Li A, Xue J, Peterson EH (2008) Architecture of the mouse utricle: macular organization and hair bundle heights. J Neurophysiol 99:718-733. CrossRef Medline

Lin V, Golub JS, Nguyen TB, Hume CR, Oesterle EC, Stone JS (2011) Inhibition of Notch activity promotes nonmitotic regeneration of hair cells in the adult mouse utricles. J Neurosci 31:15329-15339. CrossRef Medline

Luquet S, Perez FA, Hnasko TS, Palmiter RD (2005) NPY/AgRP neurons are essential for feeding in adult mice but can be ablated in neonates. Science 310:683-685. CrossRef Medline

Mbiene JP, Favre D, Sans A (1984) The pattern of ciliary development in fetal mouse vestibular receptors: a qualitative and quantitative SEM study. Anat Embryol (Berl) 170:229-238. CrossRef Medline

Mekada E, Kohno K, Ishiura M, Uchida T, Okada Y (1982) Methylamine facilitates demonstration of specific uptake of diphtheria toxin by $\mathrm{CHO}$ cell and toxin-resistant $\mathrm{CHO}$ cell mutants. Biochem Biophys Res Commun 109:792-799. CrossRef Medline

Meyers JR, MacDonald RB, Duggan A, Lenzi D, Standaert DG, Corwin JT, Corey DP (2003) Lighting up the senses: FM1-43 loading of sensory cells through nonselective ion channels. J Neurosci 23:4054-4065. Medline

Miller AJ, Dudley SD, Tsao JL, Shibata D, Liskay RM (2008) Tractable Crelox system for stochastic alteration of genes in mice. Nat Methods 5:227229. CrossRef Medline

Nakagawa T, Kim TS, Murai N, Endo T, Iguchi F, Tateya I, Yamamoto N, Naito Y, Ito J (2003) A novel technique for inducing local inner ear damage. Hear Res 176:122-127. CrossRef Medline

Oesterle EC, Stone JS (2008) Hair cell regeneration: mechanisms guiding cellular proliferation and differentiation. In: Hair cell regeneration, repair, and protection (Salvi RJ, Popper AN, Fay RR, eds), pp 141-197. New York: Springer.

Oesterle EC, Cunningham DE, Westrum LE, Rubel EW (2003) Ultrastructural analysis of $\left[{ }^{3} \mathrm{H}\right]$ thymidine-labeled cells in the rat utricular macula. J Comp Neurol 463:177-195. CrossRef Medline

Palmiter R (2001) Interrogation by toxin. Nat Biotechnol 19:731-732. CrossRef Medline

Pappenheimer AM Jr, Harper AA, Moynihan M, Brockes JP (1982) Diphtheria toxin and related proteins: effect of route of injection on toxicity and the determination of cytotoxicity for various cultured cells. J Infect Dis 145:94-102. CrossRef Medline

Roberson DF, Weisleder P, Bohrer PS, Rubel EW (1992) Ongoing production of sensory cells in the vestibular epithelium of the chick. Hear Res 57:166-174. CrossRef Medline

Rubel EW, Dew LA, Roberson DW (1995) Mammalian vestibular hair cell regeneration. Science 267:701-707. CrossRef Medline

Ryals BM, Rubel EW (1988) Hair cell regeneration after acoustic trauma in adult Coturnix quail. Science 240:1774-1776. CrossRef Medline

Saito M, Iwawaki T, Taya C, Yonekawa H, Noda M, Inui Y, Mekada E, Kimata Y, Tsuru A, Kohno K (2001) Diphtheria toxin receptor-mediated con- ditional and targeted cell ablation in transgenic mice. Nat Biotechnol 19:746-750. CrossRef Medline

Schug N, Braig C, Zimmermann U, Engel J, Winter H, Ruth P, Blin N, Pfister M, Kalbacher H, Knipper M (2006) Differential expression of otoferlin in brain, vestibular system, immature and mature cochlea of the rat. Eur J Neurosci 24:3372-3380. CrossRef Medline

Shailam R, Lanford PJ, Dolinsky CM, Norton CR, Gridley T, Kelley MW (1999) Expression of proneural and neurogenic genes in the embryonic mammalian vestibular system. J Neurocytol 28:809-819. CrossRef Medline

Si F, Brodie H, Gillespie PG, Vazquez AE, Yamoah EN (2003) Developmental assembly of transduction apparatus in chick basilar papilla. J Neurosci 23:10815-10826. Medline

Staecker H, Praetorius M, Baker K, Brough DE (2007) Vestibular hair cell regeneration and restoration of balance function induced by math 1 gene transfer. Otol Neurotol 28:223-231. CrossRef Medline

Steyger PS, Burton M, Hawkins JR, Schuff NR, Baird RA (1997) Calbindin and parvalbumin are early markers of non-mitotically regenerating hair cells in the bullfrog vestibular otolith organs. Int J Dev Neurosci 15:417432. CrossRef Medline

Stone JS, Cotanche DA (2007) Hair cell regeneration in the avian auditory epithelium. Int J Dev Biol 51:633-647. CrossRef Medline

Stone JS, Rubel EW (2000) Temporal, spatial, and morphologic features of hair cell regeneration in the avian basilar papilla. J Comp Neurol 417:116. CrossRef Medline

Taylor RR, Nevill G, Forge A (2008) Rapid hair cell loss: a mouse model for cochlear lesions. J Assoc Res Otolaryngol 9:44-64. CrossRef Medline

Tong L, Hume C, Palmiter R, Rubel EW (2011) Ablation of mouse cochlea hair cells by activating the human diphtheria toxin receptor (DTR) gene targeted to the Pou $4 \mathrm{f} 3$ locus. Paper presented at the Thirty-fourth Annual Midwinter Research Meeting of the Association for Research in Otolaryngology, Baltimore, MD, February.

Walsh RM, Hackney CM, Furness DN (2000) Regeneration of the mammalian vestibular sensory epithelium following gentamicin-induced damage. J Otolaryngol 29:351-360. Medline

Wanamaker HH, Gruenwald L, Damm KJ, Ogata Y, Slepecky N (1998) Dose-related vestibular and cochlear effects of transtympanic gentamicin. Am J Otol 19:170-179. CrossRef Medline

Wang GP, Chatterjee I, Batts SA, Wong HT, Gong TW, Gong SS, Raphael Y (2010) Notch signaling and Atoh1 expression during hair cell regeneration in the mouse utricle. Hear Res 267:61-70. CrossRef Medline

Warchol ME, Lambert PR, Goldstein BJ, Forge A, Corwin JT (1993) Regenerative proliferation in inner ear sensory epithelia from adult guinea pigs and humans. Science 259:1619-1622. CrossRef Medline

Weisleder P, Rubel EW (1993) Hair cell regeneration after streptomycin toxicity in the avian vestibular epithelium. J Comp Neurol 331:97-110. CrossRef Medline

Weisleder P, Tsue TT, Rubel EW (1995) Hair cell replacement in avian vestibular epithelium: supporting cell to type I hair cell. Hear Res 82:125133. CrossRef Medline

Whitehead MC, Morest DK (1985) The development of innervation patterns in the avian cochlea. Neuroscience 14:255-276. CrossRef Medline

Wu WJ, Sha SH, McLaren JD, Kawamoto K, Raphael Y, Schacht J (2001) Aminoglycoside ototoxicity in adult CBA, C57BL and BALB mice and the Sprague-Dawley rat. Hear Res 158:165-178. CrossRef Medline

Xiang M, Gan L, Li D, Chen ZY, Zhou L, O’Malley BW Jr, Klein W, Nathans $J$ (1997) Essential role of POU-domain factor Brn-3c in auditory and vestibular hair cell development. Proc Natl Acad Sci U S A 94:9445-9450. CrossRef Medline

Yamaizumi M, Mekada E, Uchida T, Okada Y (1978) One molecule of diphtheria toxin fragment A introduced into a cell can kill the cell. Cell 15:245250. CrossRef Medline

Zakir M, Dickman JD (2006) Regeneration of vestibular otolith afferents after ototoxic damage. J Neurosci 26:2881-2893. CrossRef Medline 